\title{
Other Chemical Constituents Isolated from Solanum crinitum Lam. (Solanaceae)
}

\author{
Marli T. F. Cornelius, ${ }^{a}$ Mário G. de Carvalho, ${ }^{* a}{ }^{a}$ Tania M. S. da Silva, ${ }^{a}$ \\ Cassia C. F. Alves, ${ }^{a}$ Ana P. N. Siston, ${ }^{a}$ Kelly Z. Alves, ${ }^{a}$ Carlos M. R. Sant'Anna, ${ }^{a}$ \\ Mario B. Neto, ${ }^{b}$ Marcos N. Eberlin ${ }^{b}$ and Raimundo Braz-Filho ${ }^{c}$ \\ ${ }^{a}$ Departamento de Química, ICE, Universidade Federal Rural do Janeiro, BR $465 \mathrm{~km}$ 07, \\ 23890-000 Seropédica-RJ, Brazil
}

${ }^{b}$ Instituto de Química, Universidade Estadual de Campinas, 13084-862 Campinas-SP, Brazil

${ }^{c}$ Setor de Química de Produtos Naturais, LCQUI, CCT, Universidade Estadual do Norte Fluminense Darcy Ribeiro, 28013-602 Campos dos Goytacazes-RJ, Brazil

\begin{abstract}
O estudo fitoquímico de Solanum crinitum Lam forneceu quatro flavonóides: tilirosídeo (1), astragalina (2), kaempferol (3) e biochanina A-7- $O$ - $\beta$-D-apiofuranosil- $(1 \rightarrow 5)-\beta$-D-apiofuranosil$(1 \rightarrow 6)-\beta$-D-glucopiranosideo (7), ácido 4-hidroxibenzoico (12), e quatro derivados do ácido cinâmico: cis- e trans- cumárico (10 e 11), cis- e trans-cumarato de etila (8 e 9), isolados de tricomas do fruto. Do extrato metanólico de frutos verdes foram isolados três alcalóides esteroidais glicosilados: solamargina (13), 20-epi-solamargina (14) e solasonina (16). Os derivados 3,5,7,4'-tetra- $O$-metil-kaempferol (4), 3,7,4'-tri- $O$-metil-kaempferol (5), 3,7,4'-tri- $O$-metil-5- $O$ acetil-kaempferol (6), peracetil-epi-solamargina (15) e peracetil-solasonina (17) foram sintetizados e estão sendo registrados pela primeira vez na literatura. As estruturas foram definidas através de análise de dados espectrométricos.
\end{abstract}

The phytochemical investigation of Solanum crinitum Lam led to the isolation from the fruit trichomes of four flavonoids, tiliroside (1), astragalin (2), kaempferol (3), biochanin A-7$O$ - $\beta$-D-apiofuranosyl- $(1 \rightarrow 5)-\beta$-D-apiofuranosyl- $(1 \rightarrow 6)-\beta$-D-glucopyranoside $(7)$, along with 4-hydroxybenzoic acid (12), and four cinnamic acid derivatives, cis- and trans-coumaric acids (10 and 11) and cis- and trans- ethyl coumarate ( $\mathbf{8}$ and $\mathbf{9})$. Three tri-glycosyl-steroidal alkaloids, solamargine (13), 20-epi-solamargine (14) and solasonine (16) were isolated from the methanolic extract of the green fruits. The derivatives 3,5,7,4'-tretra- $O$-methyl-kaempferol (4), 3,7,4'-tri$O$-methyl-kaempferol (5), 3,7,4'-tri- $O$-methyl-5- $O$-acetyl-kaempferol (6), the peracetyl-episolamargine (15) and peracetyl-solasonine (17) were prepared. The structures were established through the analysis of their spectral data. The complete ${ }^{1} \mathrm{H}$ and ${ }^{13} \mathrm{C}$ NMR data assignments of the new peracetyl derivatives of the alkaloids were made.

Keywords: Solanum crinitum, Solanaceae, steroidal glycoalkaloids, flavonoids, cinnamic acids

\section{Introduction}

Solanum (L) is the most representative genus of Solanaceae, containing about 1,500 species, and 5,000 epithets. It is widespread in tropical and subtropical regions of all the world, but its highest diversity occurs in South America. ${ }^{1}$ Solanum species are a rich source of steroidal alkaloids, flavonoids and their glycosides which are known to possess a variety of biological activities. The glycoalkaloids are natural toxins with ecological and human health importance, such as the allelopathic effect

\footnotetext{
*e-mail: mgeraldo@ufrrj.br
}

against herbivores, against pathogenic microorganism ${ }^{2,3}$ and molluscicidal activity, ${ }^{4}$ and are also of interest as starting material for anabolic, anti-fertility, anti-inflammatory, anti-allergic drugs. ${ }^{5}$ As the alkaloids, the flavonoids are a frequent group of compounds in Solanum species, and can be used as systematic markers for the family taxons. ${ }^{6-8}$

Solanum crinitum Lam (Solanaceae), popularly known as "jurubeba" and "fruto-de-lobo", is a shrub or small tree in South America, including southern Brazil and Colombia. ${ }^{9} 10$ In the course of our pharmacological and phytochemical investigations of Solanum species, ${ }^{3,4,8,11-13}$ we have reported the cytotoxic and antitumoral activities of flavonoids isolated from trichomes of young branches 
and also of a rich glycoalkaloids total fraction from the green fruits of Solanum crinitum Lam $^{14}$ along with its allelopathic activity. ${ }^{3}$

This work describes the isolation and structural characterization of the flavonoids tiliroside (1), astragalin (2), kaempferol (3) and biochanin A-7-O- $\beta$ D-apiofuranosyl- $(1 \rightarrow 5)-\beta$-D-apiofuranosyl- $(1 \rightarrow 6)-\beta$-Dglucopyranoside (7), cis- (10) and trans- (11) cumaric acids and ethyl cis- $(\mathbf{8})$ and trans- $(\mathbf{9})$ cumarate and 4-hydroxybenzoic acid (12), which were isolated from the trichomes, and the glycoalkaloids solamargine (13), 20-epi-solamargine (14) and solasonine (16) isolated from the green fruits. The derivatives 3,5,7,4'-tetra- $O$ methyl-kaempferol (4), 3,7,4'-tri- $O$-methyl-kaempferol (5), 3,7,4'-tri- $O$-methyl-5- $O$-acetyl-kaempferol (6), peracetyl-epi-solamargine (15) and peracetyl-solasonine (17) were prepared and used to confirm the structures of the natural compounds. The structures were established through analysis of their spectral data, mainly NMR (1D and 2D) and mass spectra. NMR data for the new acetyl derivatives of the alkaloids are described herein for the first time.

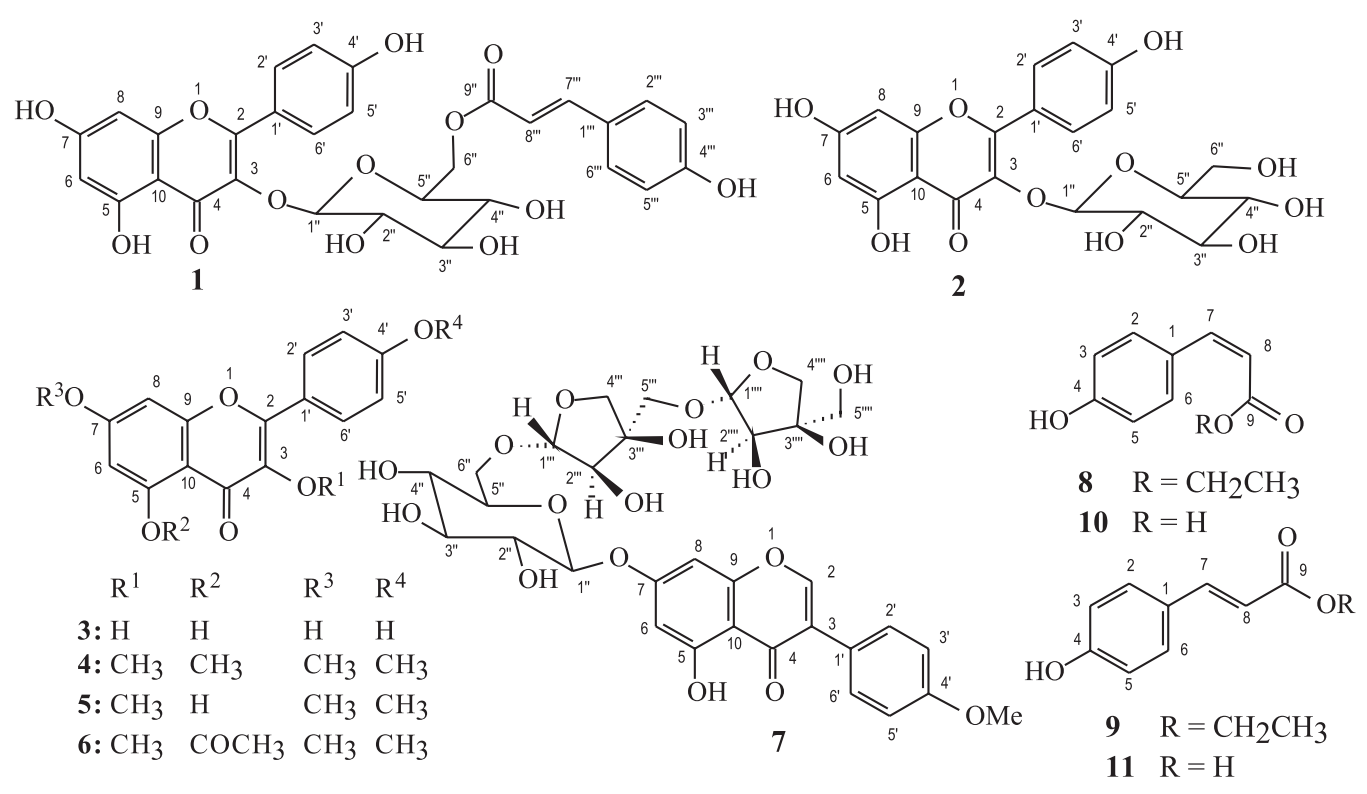

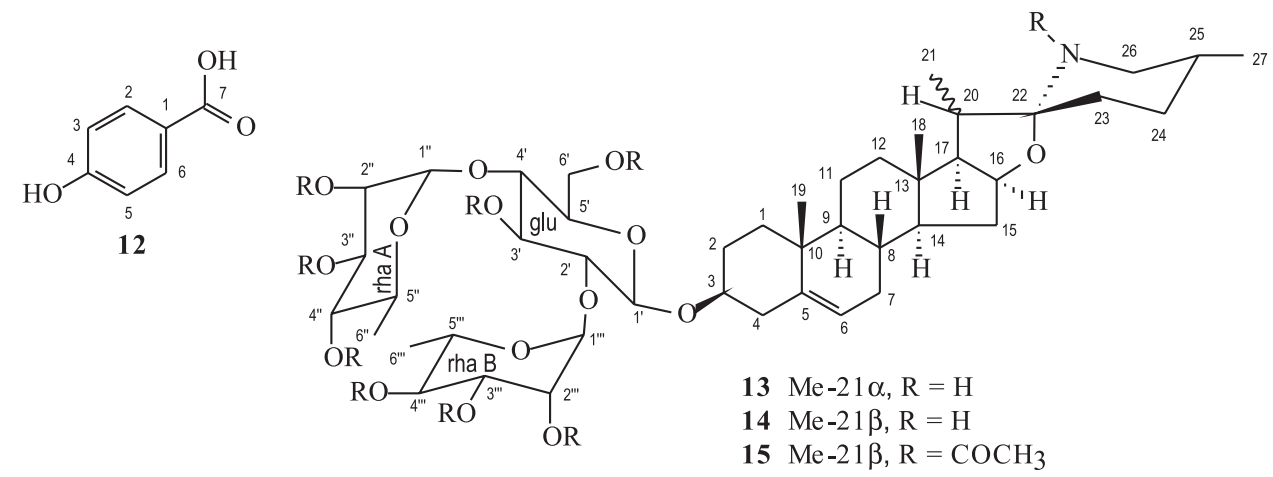

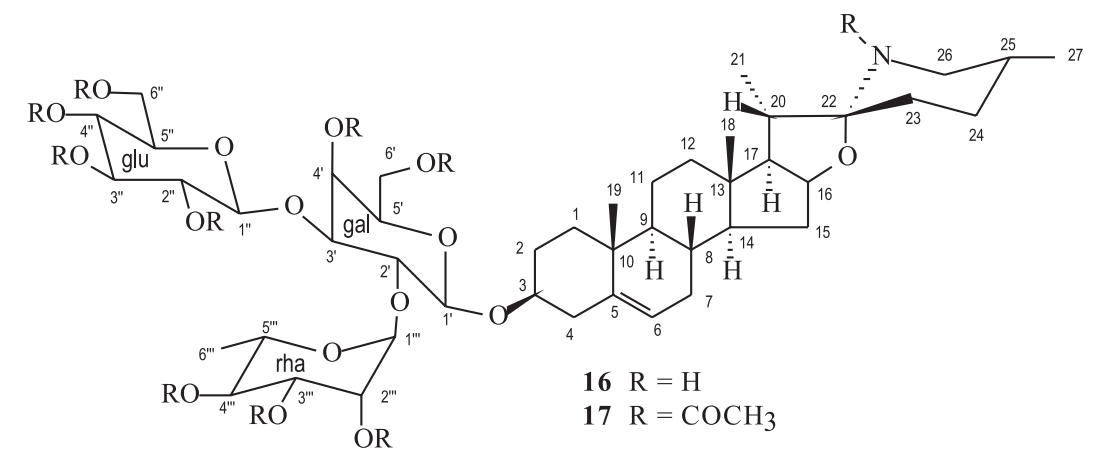




\section{Results and Discussion}

From the trichomes isolated from green fruits of Solanum crinitum Lam were isolated the flavonoids: tiliroside (1), astragalin (2), kaempferol (3), and biochanin A-7-O- $\beta$ D-apiofuranosyl- $(1 \rightarrow 5)-\beta$-D-apiofuranosyl- $(1 \rightarrow 6)-\beta$-Dglucopyranoside (7), cis- (10) and trans- (11) cumaric acids and ethyl cis- (8) and trans- (9) cumarate esters and 4-hydroxybenzoic acid (12); from green fruits methanolic extracts were isolated three tri-glycosyl-steroidal alkaloids, solamargine (13), 20-epi-solamargine (14) and solasonine (16). The derivatives 3,5,7,4'-tetramethylkaempferol (4), 3,7,4'-trimethylkaempferol (5), 3,7,4'-trimethyl-5acetylkaempferol (6), the peracetyl-20-epi-solamargine (15) and peracetyl-solasonine (17) were prepared. The structures were established on the basis of IR, NMR and MS data analysis of the natural compounds and of the derivatives 4-6, 15 and 17.

Compounds 1-3 were identified by the analysis of ${ }^{1} \mathrm{H}$ and ${ }^{13} \mathrm{C}$ NMR spectra, including HMQC and HMBC experiments, and comparison with literature data for tiliroside, kaempferol and astragalin. ${ }^{15-18}$ The first report of $\mathbf{1}$ in Solanum species was made by Souza et al. ${ }^{14}$ Kaempferol and astragalin have been isolated from some Solanum species. ${ }^{8}$ The treatment of $\mathbf{3}$ with diazomethane yielded the methyl derivatives $\mathbf{4}$ and $\mathbf{5}$, described in the literature, ${ }^{19}$ and the derivative $\mathbf{6}$ was obtained by treating 5 with $\mathrm{Ac}_{2} \mathrm{O} /$ Pyridine. The 2D NMR spectra, including NOESY experiments, of these derivatives were used to confirm the proposed structure of $\mathbf{3}$ and to carry out the complete assignment of the ${ }^{1} \mathrm{H}$ and ${ }^{13} \mathrm{C}$ chemical shifts of 6 (see Experimental).

The ${ }^{1} \mathrm{H}$ and ${ }^{13} \mathrm{C}$ NMR spectra of compound 7 revealed characteristic resonances of the isoflavonoid biochanin A besides additional signals for three sugars unities, one glucopyranoside and two apiofuranosides. Comparison of these data with those of glycosides isolated from Dalbergia nigra ${ }^{20}$ and Andira anthelmia ${ }^{21}$ besides the analysis of mass spectrum obtained by FAB-MS in positive mode $\left\{\mathrm{m} / \mathrm{z} 733.20820\left([\mathrm{M}+\mathrm{Na}]^{+}, \mathrm{C}_{32} \mathrm{H}_{38} \mathrm{O}_{18}+\mathrm{Na}^{+}\right.\right.$, calc.: $\mathrm{m} / \mathrm{z}$ 733.19558), $\mathrm{m} / \mathrm{z} 601.12300[\mathrm{M}+\mathrm{Na}-132]^{+}, \mathrm{m} / \mathrm{z}$ $451.0600(\mathrm{M}+\mathrm{Na}-282)^{+}, \mathrm{m} / z 449.27710[\mathrm{M}+\mathrm{Na}-284]^{+}, \mathrm{m} / \mathrm{z}$ $431.16210[\mathrm{M}+\mathrm{Na}-302]^{+}, \mathrm{m} / \mathrm{z} 317.1338[\mathrm{M}+\mathrm{Na}-416]^{+}, \mathrm{m} / \mathrm{z}$ $\left.287.0865[\mathrm{M}+\mathrm{Na}-446]^{+}\right\}$, led us to identify the compound as biochanin A, 7- $O$ - $\beta$-D-apiofuranosyl- $(1 \rightarrow 5)-\beta$-Dapiofuranosyl- $(1 \rightarrow 6)-\beta$-D-glucopyranoside (7). This is the first report of this apiofuranosyl derivative in Solanum species.

Compounds 8-12 were identified by the ${ }^{1} \mathrm{H}$ and ${ }^{13} \mathrm{C}$ NMR spectral data analysis of the mixtures of $\mathbf{8}+\mathbf{9}$, $\mathbf{1 0}+\mathbf{1 1}$ and of $\mathbf{1 2}$ along with comparison with literature data. ${ }^{21-25}$ The integration of the ${ }^{1} \mathrm{H}$ NMR signals allowed us to calculate the approximate relative percentage of both compounds: $36.16 \%$ of $\mathbf{8}$ and $63.84 \%$ of $\mathbf{9}$.

The fractions containing compounds 13,14 and 16 showed a positive test for alkaloids. The detailed analysis of the ${ }^{1} \mathrm{H}$ and ${ }^{13} \mathrm{C}$ NMR spectra of the isolated compounds allowed to identify characteristic signals corresponding to the same aglycone as that of the steroidal spirazolane-type alkaloid in the three glycoalkaloids: four quaternary carbon atoms, including one linked to oxygen and nitrogen atoms: $\left(\delta_{\mathrm{C}} 98.7\right.$ to 98.5 and one $\mathrm{sp}^{2}$ at $\delta_{\mathrm{C}} 141.2$ to 140.4$)$, nine methine groups (including two oxygenated at $\delta_{\mathrm{C}} 78.5$ to 78.0 and 81.1 to 78.6), ten methylene groups and four methyl groups $=(\mathrm{C})_{3}(\mathrm{O}-\mathrm{C}-\mathrm{NH})(\mathrm{CH})_{7}(\mathrm{HC}-\mathrm{O})_{2}\left(\mathrm{CH}_{2}\right)_{10}\left(\mathrm{CH}_{3}\right)_{4}=$ $\mathrm{C}_{27} \mathrm{H}_{42} \mathrm{NO}_{3}=\mathrm{C}_{27} \mathrm{H}_{42} \mathrm{NO}_{2}$ considering the presence of an ether function (Table 1) having a trisaccharide moiety (three anomeric carbon atoms: $\delta_{\mathrm{C}} 100.6$ to 100.3 ) attached to the oxygen atom of carbon $\mathrm{CH}-3$, with $\delta_{\mathrm{C}} 78.5$ to 78.0 (Table 1 and 2), which is significantly higher when compared with the ${ }^{13} \mathrm{C}$ chemical shift of the methyl carbon CH-3 sustaining free hydroxyl group (about $\delta_{\mathrm{C}} 71$ ). The ${ }^{1} \mathrm{H}$ and ${ }^{13} \mathrm{C}$ chemical shifts of the trisaccharide moieties of $\mathbf{1 3}$ and 14, had practically the same values (Table 2), indicating identical the partial structure $O$ - $[\alpha-$ L-rhamnopyranosyl- $(1 \rightarrow 2)$ - $O$-[ $\alpha$-L-rhamnopyranosyl$(1 \rightarrow 4)]$ - $\beta$-D-glucopyranoside $=\mathrm{C}_{18} \mathrm{H}_{32} \mathrm{O}_{13}$ (three degrees of unsaturation, $\mathrm{C}_{18} \mathrm{H}_{38} \mathrm{O}_{13}-\mathrm{C}_{18} \mathrm{H}_{32} \mathrm{O}_{13}=\mathrm{H}_{6}$ ). On the other hand, the ${ }^{1} \mathrm{H}$ and ${ }^{13} \mathrm{C}$ signals observed in NMR spectra of 16 allowed to characterize the trisaccharide as $O-[\alpha-\mathrm{L}-$ rhamnopyranosyl-( $(1 \rightarrow 2)-O$-[ $\beta$-glucopyranosyl- $(1 \rightarrow 3)]$ $\beta$-D-galactopyranoside $=\mathrm{C}_{18} \mathrm{H}_{32} \mathrm{O}_{14}$ (three degrees of unsaturation, $\mathrm{C}_{18} \mathrm{H}_{38} \mathrm{O}_{14}-\mathrm{C}_{18} \mathrm{H}_{32} \mathrm{O}_{14}=\mathrm{H}_{6}$ ). All these NMR spectral data allowed to deduce the same molecular formulas $\mathrm{C}_{45} \mathrm{H}_{73} \mathrm{NO}_{15}$ to $\mathbf{1 3}$ and $\mathbf{1 4}$ and $\mathrm{C}_{45} \mathrm{H}_{73} \mathrm{NO}_{16}$ to $\mathbf{1 6}$, all with ten degrees of unsaturation corresponding to one double bond and six rings). In fact, the values of pseudomolecular peaks in the positive HRMS spectra at $\mathrm{m} / \mathrm{z} 868.5239$ $\left(\mathrm{M}+\mathrm{H}^{\circ+}, 100 \%\right)$ of $\mathbf{1 3}\left(\mathrm{C}_{45} \mathrm{H}_{74} \mathrm{NO}_{15}=m / z\right.$ 868.5058) and at $\mathrm{m} / \mathrm{z} 868.5305\left(\mathrm{M}+\mathrm{H}^{++}, 100 \%\right)$ of $\mathbf{1 4}\left(\mathrm{C}_{45} \mathrm{H}_{74} \mathrm{NO}_{15}=\mathrm{m} / \mathrm{z}\right.$ 868.5058), besides additional peaks compatible with loss of sugar moieties, were used to confirm the molecular formula of these isomeric compounds (13 and 14). The hydrogen and carbon atoms signals observed in the ${ }^{1} \mathrm{H}$ and ${ }^{13} \mathrm{C}$ NMR spectra of 13-17 (Tables 1 and 3) were also assigned with aid of the homonuclear $2 \mathrm{D}^{1} \mathrm{H}-{ }^{1} \mathrm{H}-\mathrm{COSY}$ and heteronuclear 2D HMQC $\left({ }^{1} \mathrm{H}^{-13} \mathrm{C}^{-} \mathrm{COSY}-{ }^{1} J_{\mathrm{CH}}\right)$ and $\mathrm{HMBC}$ $\left({ }^{1} \mathrm{H}-{ }^{13} \mathrm{C}-\mathrm{COSY} Y-{ }^{\mathrm{n}} J_{\mathrm{CH}}, \mathrm{n}=2\right.$ and 3 ), allowing to identify the ${ }^{1} \mathrm{H}$ chemical shifts of the methyl group signals of the aglycone and of the trisaccharide moieties (Table 3 and 4 ): $\delta_{\mathrm{H}} 0.83$ (d, 3H-27), 0.88 (s, 3H-18), 1.07 (s, 3H-19) and 1.09 (d, $3 \mathrm{H}-21)$ of 13, 0.79 (d, 3H-27), 0.85 (s, 3H-18), 1.06 (s, 
$3 \mathrm{H}-19)$ and 1.28 (d, 3H-21) of 14, and 0.76 (d, 3H-27), 0.82 (s, 3H-18), 1.03 (s, 3H-19) and 1.17 (d, 3H-21) of 16; signals of the hydrogen $\mathrm{H}-6$ linked to $\mathrm{sp}^{2}$ carbons of double bounds at $\delta_{\mathrm{H}}: 5.32(\mathbf{1 3}), 5.33(\mathbf{1 4}), 5.30(\mathbf{1 6})$, besides the signals of $\mathrm{H}-16$ located in the spyrazolane ring $(\mathrm{d}, J 6 \mathrm{~Hz})$ at $\delta_{\mathrm{H}} 4.42$ (13); 4.82 (14) and 4.21 (16). The additional doublets $(J 6 \mathrm{~Hz})$ corresponding to methyl groups were revealed at $\delta_{3 \mathrm{H}} 1.64$ and $\delta_{3 \mathrm{H}} 1.78$ in the spectra of $\mathbf{1 3}$ and $\mathbf{1 4}$ suggested the presence of two rhamnose moieties in both compounds and only one rhamnose for $\mathbf{1 6}$ as indicated by signal at $\delta_{\mathrm{H}}$ 1.78. The differences observed in the ${ }^{1} \mathrm{H}$ NMR spectra of 13 and 14, recorded in same apparatus $\left({ }^{1} \mathrm{H}: 500 \mathrm{MHz}\right.$; ${ }^{13} \mathrm{C}$ : $125 \mathrm{MHz}$ ) and solvent pyridine- $d_{5}$, involving mainly the chemical shifts of the hydrogen atoms $\mathrm{H}-16\left(\delta_{\mathrm{H}} 4.42\right.$ and 4.82), $\mathrm{H}-17\left(\delta_{\mathrm{H}} 1.78\right.$ and 2.02), $\mathrm{H}-20\left(\delta_{\mathrm{H}} 1.98\right.$ and 2.14$)$, $2 \mathrm{H}-26\left(\delta_{\mathrm{H}} 2.78\right.$ and 3.04/2.89) and 3H-21 $\left(\delta_{\mathrm{H}} 1.09\right.$ and 1.28), which revealed correlation in the HMQC with the ${ }^{13} \mathrm{C}$ signals of the corresponding carbon atoms: $\mathrm{CH}-16\left(\delta_{\mathrm{C}} 79.2\right.$ and 81.1), $\mathrm{CH}-17\left(\delta_{\mathrm{C}} 63.9\right.$ and 63.0), $\mathrm{CH}-20\left(\delta_{\mathrm{C}} 42.0\right.$ and $42.0), \mathrm{CH}_{2}-26\left(\delta_{\mathrm{C}} 48.2\right.$ and 47.1$)$ and $3 \mathrm{H}-21\left(\delta_{\mathrm{C}} 16.1\right.$ and 15.7), as summarized in Figure 1. Comparative analysis of these data was used to suggest the two stereoisomers $\mathrm{H}-20 \beta(\mathbf{1 3})$ and $\mathrm{H}-20 \alpha(\mathbf{1 4})$, since the $22 \alpha \mathrm{N}$ and $22 \beta \mathrm{N}$ possibilities were eliminated considering the absence of ${ }^{13} \mathrm{C}$ signal corresponding to a methylene carbon $\mathrm{CH}_{2}-23$ at about $\delta_{\mathrm{C}} 27$ which is consistent with the ${ }^{13} \mathrm{C} \mathrm{NMR}$ chemical

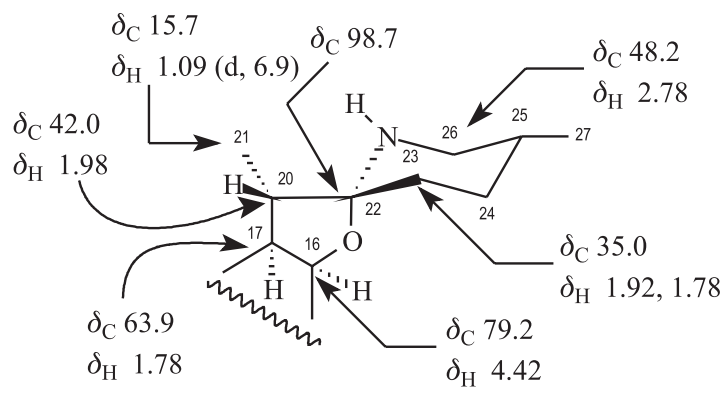

13

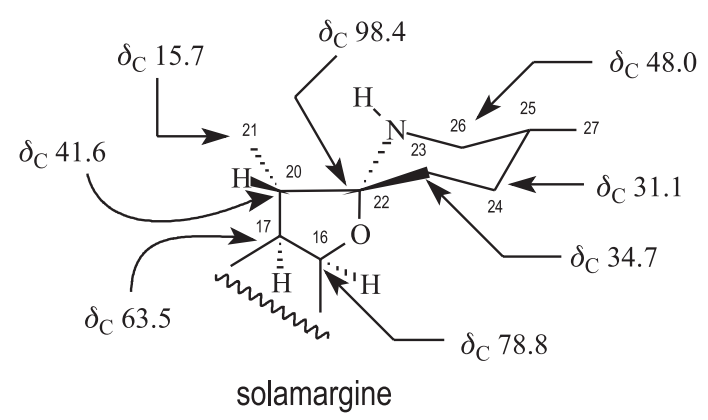

shift of the $22 \beta \mathrm{N}$ stereoisomer (Figure 1). The $\beta$-position of the methyl Me-21 located at carbon atom 20 of $\mathbf{1 4}$ may be used to justify the ${ }^{13} \mathrm{C}$ chemical shifts of the $\mathrm{CH}-16$ $\left(\delta_{\mathrm{C}} 81.1\right.$, absence of the $\gamma$-effect from Me-21) and $\mathrm{CH}_{2}-23$ $\left(\delta_{\mathrm{C}} 34.0\right.$, presence of the $\gamma$-effect from Me-21). ${ }^{26-30}$ In order to compare the relative stabilities of the epimeric structures 13/14, a molecular modeling study was implemented using the Spartan 06 for Linux program (Wavefunction, Inc.), see Supplementary Information. ${ }^{31}$

The complete ${ }^{1} \mathrm{H}$ and ${ }^{13} \mathrm{C}$ chemical shift assignments of the signals of $\mathrm{CH}_{3}, \mathrm{CH}_{2}, \mathrm{CH}$ and $\mathrm{C}$ observed in the ${ }^{1} \mathrm{H}$ (including $\left.{ }^{1} \mathrm{H}-{ }^{1} \mathrm{H}-\mathrm{COSY}\right)$ and ${ }^{13} \mathrm{C}\left(\left\{{ }^{1} \mathrm{H}\right\}\right.$ and DEPT) NMR spectra (including 2D experiments HMQC and HMBC) (Tables 1, 2, 3 and 4) and comparison with values described in the literature for solamargine $(\mathbf{1 3})^{26-29}$ and solasonine $(\mathbf{1 6})^{28,31}$ led to the proposition of the structures $(25 R)$ $(20 S)(16 S)-3 \beta-\{O$ - $\alpha$-L-rhamnopyranosyl- $(1 \rightarrow 2)-O$ - $[\alpha-\mathrm{L}-$ rhamnopyranosyl- $(1 \rightarrow 4)]-\beta$-D-glucopyranosyl $\}-22 \alpha N$ spirosol-5-en (solamargine, 13), the new glycoalkaloid $(25 R)(20 R)(16 S)-3 \beta-\{O-\alpha-\mathrm{L}-$ rhamnopyranosyl- $(1 \rightarrow 2)$ $O$-[ $\alpha$-L-rhamnopyranosyl- $(1 \rightarrow 4)]-\beta$-D-glucopyranosyl $\}$ $22 \alpha N$-spirosol-5-en (16-epi-solamargine, 14), and (25R) $(20 S)(16 S)-3 \beta-\{O-\alpha$-L-rhamnopyranosyl- $(1 \rightarrow 2)-O-[\beta-$ glucopyranosyl- $(1 \rightarrow 3)]-\beta$-D-galactopyranosyl $\}-22 \alpha N$ spirosol-5-en (solasonine, 16) for the three steroidal glycoalkaloids isolated from this plant (Figure 1).

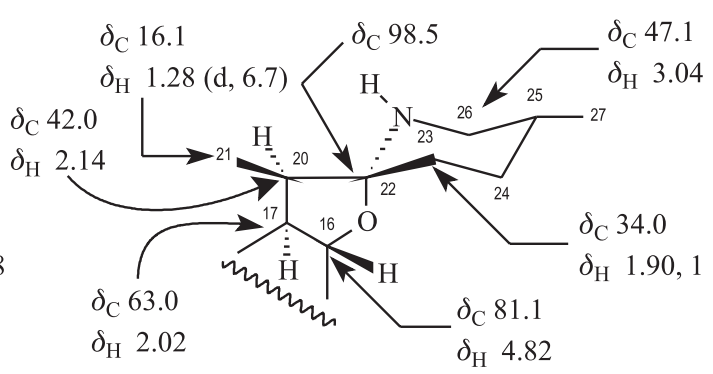

14

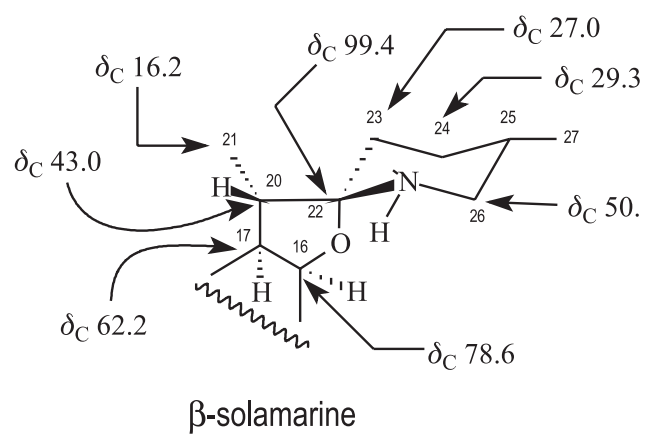

Figure 1. Comparative analysis of the chemical shifts corresponding to the hydrogen $\left(\delta_{\mathrm{H}}\right)$ and carbon $\left(\delta_{\mathrm{C}}\right)$ atoms $\mathrm{CH}-16, \mathrm{CH}-17, \mathrm{CH}_{-}-20, \mathrm{CH}_{3}-21, \mathrm{C}-22$, $\mathrm{CH}_{2}-23$ and $\mathrm{CH}_{2}-26$ of $\mathbf{1 3}$ and 14, including comparison of the $\delta_{\mathrm{C}}$ these carbon atoms and of the $\mathrm{CH}_{2}-24$ to reveal the structural distinction between solamargine and $\beta$-solamarine. 
Table 1. ${ }^{13} \mathrm{C}$ NMR spectral data for aglycone of 13,14 and 16 in pyridine- $d_{5}$ (125 MHz: 13 and 14; $50 \mathrm{MHz}$ : 16) and of peracetyl derivatives $\mathbf{1 5}$ and 17 in $\mathrm{CDCl}_{3}(125 \mathrm{MHz}) *$

\begin{tabular}{|c|c|c|c|c|c|}
\hline $\mathrm{C}$ & 13 & 14 & $15^{\mathrm{a}}$ & 16 & $17^{\mathrm{a}}$ \\
\hline $1\left(\mathrm{CH}_{2}\right)$ & 37.9 & 37.5 & 37.3 & 37.6 & 37.1 \\
\hline $2\left(\mathrm{CH}_{2}\right)$ & 30.5 & 30.2 & 29.7 & 30.2 & 29.5 \\
\hline $3(\mathrm{CH})$ & 78.5 & 78.0 & 79.3 & 78.4 & 79.8 \\
\hline $4\left(\mathrm{CH}_{2}\right)$ & 39.3 & 39.0 & 38.4 & 38.8 & 38.4 \\
\hline $5(\mathrm{C})$ & 141.2 & 140.4 & 140.4 & 141.0 & 140.2 \\
\hline $6(\mathrm{CH})$ & 122.2 & 121.9 & 122.2 & 121.8 & 121.9 \\
\hline $7\left(\mathrm{CH}_{2}\right)$ & 32.1 & 32.3 & 31.8 & 32.3 & 31.6 \\
\hline $8(\mathrm{CH})$ & 32.0 & 31.7 & 31.6 & 31.8 & 31.4 \\
\hline $9(\mathrm{CH})$ & 50.7 & 50.3 & 50.3 & 50.3 & 50.0 \\
\hline $10(\mathrm{C})$ & 37.5 & 37.2 & 36.9 & 37.2 & 36.7 \\
\hline $11\left(\mathrm{CH}_{2}\right)$ & 21.5 & 21.1 & 21.0 & 21.2 & 20.6 \\
\hline $12\left(\mathrm{CH}_{2}\right)$ & 40.5 & 39.7 & 40.0 & 39.9 & 39.8 \\
\hline $13(\mathrm{C})$ & 41.0 & 40.8 & 42.9 & 40.8 & 42.7 \\
\hline $14(\mathrm{CH})$ & 57.0 & 56.5 & 53.0 & 56.6 & 54.8 \\
\hline $15\left(\mathrm{CH}_{2}\right)$ & 32.9 & 32.6 & 31.6 & 32.6 & 31.6 \\
\hline $16(\mathrm{CH})$ & 79.2 & 81.1 & 75.9 & 78.6 & 75.6 \\
\hline $17(\mathrm{CH})$ & 63.9 & 63.0 & 62.1 & 63.2 & 62.0 \\
\hline $18\left(\mathrm{CH}_{3}\right)$ & 16.9 & 16.4 & 12.8 & 16.5 & 12.4 \\
\hline $19\left(\mathrm{CH}_{3}\right)$ & 19.8 & 19.4 & 19.4 & 19.5 & 20.3 \\
\hline $20(\mathrm{CH})$ & 42.0 & 42.0 & 40.0 & 41.9 & 39.7 \\
\hline $21\left(\mathrm{CH}_{3}\right)$ & 16.1 & 15.7 & 21.1 & 15.8 & 21.4 \\
\hline $22(\mathrm{C})$ & 98.7 & 98.5 & 99.7 & 98.5 & 99.2 \\
\hline $23\left(\mathrm{CH}_{2}\right)$ & 35.0 & 34.0 & 35.2 & 34.3 & 35.0 \\
\hline $24\left(\mathrm{CH}_{2}\right)$ & 31.4 & 30.0 & 30.1 & 30.5 & 30.8 \\
\hline $25(\mathrm{CH})$ & 32.1 & 31.7 & 29.1 & 30.8 & 28.9 \\
\hline $26\left(\mathrm{CH}_{2}\right)$ & 48.2 & 47.1 & 45.5 & 47.5 & 45.2 \\
\hline $27\left(\mathrm{CH}_{3}\right)$ & 20.1 & 19.2 & 18.5 & 19.5 & 19.2 \\
\hline
\end{tabular}

* Number of hydrogens bound to carbon atoms deduced by comparative analysis of $\left\{{ }^{1} \mathrm{H}\right\}$ - and DEPT- ${ }^{13} \mathrm{C}$ NMR spectra. $2 \mathrm{D}{ }^{1} \mathrm{H}-{ }^{1} \mathrm{H}-\mathrm{COSY}$ and ${ }^{1} \mathrm{H}-{ }^{13} \mathrm{C}-{ }^{\mathrm{n}} J_{\mathrm{CH}}$ (n = 2 and 3) NMR spectra were also used in these assignments; ${ }^{\mathrm{a}} \delta_{\mathrm{COCH}_{3}}: 170.1-170.2(\mathrm{CO}), 23.8\left(\mathrm{CH}_{3}\right)$.

The natural alkaloids $\mathbf{1 4}$ and $\mathbf{1 6}$ were treated with $\mathrm{Ac}_{2} \mathrm{O} /$ pyridine to yield the peracetyl derivatives $\mathbf{1 5}$ and 17. The ${ }^{1} \mathrm{H}$ and ${ }^{13} \mathrm{C}$ NMR spectral data of these peracetyl derivatives (15 and 17), obtained through the analysis of extensive 1D and 2D NMR experiments (Tables 1-4), were also used to confirm the postulated structures to $\mathbf{1 4}$ and $\mathbf{1 6}$. The analysis of 1D and 2D NMR spectra was also used to make the complete hydrogen and carbon- 13 chemical shift assignments for the alkaloid, the new 16-epi-solamargine (14) and for the two peracetyl derivatives $\mathbf{1 5}$ and $\mathbf{1 7}$.

\section{Experimental}

\section{General procedure}

Melting points have not been corrected. IR, NMR and mass spectra were recorded on the same equipments used in previous papers. ${ }^{21,32}$ Column chromatography was carried out with silica gel (Vetec and Aldrich 0.05-0.20 mm) and Sephadex LH-20 (Sigma, USA); silica gel F254 G (Vetec) was used for preparative TLC; aluminum backed (Sorbent) silica gel plates W/UV254 were used for analytical TLC, with visualization under $\mathrm{UV}$ ( 254 and $366 \mathrm{~nm}$ ), with $\mathrm{AlCl}_{3}-$ ETOH (1\%), Liebermann-Burchard and/or Godin reagents, or exposure to iodine vapor.

\section{Plant material}

The green fruits of Solanum crinitum Lam. were collected in September, 2001, in the campus of Universidade Federal Rural do Rio de Janeiro (UFRRJ), Seropédica-RJ, Brazil. They were collected by M.Sc. José Milton Alves (Agronomy Institute, UFRRJ). The identification was made by Dr. Maria de Fátima Agra, Laboratório de Tecnologia Farmacêutica, Universidade Federal da Paraíba, João Pessoa-PB. A voucher specimen (No. JP-28000) was deposited at the Herbarium Prof. Lauro Pires Xavier, Universidade Federal da Paraíba, João Pessoa-PB, Brazil.

\section{Extraction and isolation}

The trichomes $(9.7 \mathrm{~g})$ were isolated by scraping the green fruits with a glass slide and were subsequently extracted with $\mathrm{CHCl}_{3}$ and $\mathrm{MeOH}$ in an ultrasound bath to furnish the $\mathrm{CHCl}_{3}$ extract $(310.0 \mathrm{mg})$ and $\mathrm{MeOH}(3.0 \mathrm{~g})$ residues. The $\mathrm{CHCl}_{3}$ residue was chromatographed on a sephadex $\mathrm{CC}$, using $\mathrm{MeOH}$ as eluent, and 13 fractions were collected and analyzed by TLC and ${ }^{1} \mathrm{H}$ NMR spectroscopy. Fractions 7-8 yielded astragaline $(\mathbf{1}, 10.0 \mathrm{mg})$ and fractions 9-10 yielded the tilirozide $(\mathbf{2}, 25.0 \mathrm{mg})$. The methanolic extract was chromatographed on a silica gel column (col A) and 20 fractions were collected and analyzed by TLC plate. Fractions 5-8 (2.0 g) were dissolved in methanol and addition of $\mathrm{CH}_{2} \mathrm{Cl}_{2}$ yielded a precipitate that was separated by filtration to afford a solid ( $1.6 \mathrm{~g})$ that was identified as kaempferol $\left(3, \mathrm{mp} 282-284^{\circ} \mathrm{C}\right)$ and the mother liquor (AM-5-8). The reaction of kaempferol $(65.0 \mathrm{mg})$ with diazomethane yielded $16.1 \mathrm{mg}$ of $\mathbf{4}\left(\mathrm{mp} 128-130{ }^{\circ} \mathrm{C}\right)$ and $36.6 \mathrm{mg}$ of $5\left(\mathrm{mp} 140-142{ }^{\circ} \mathrm{C}\right)$ that were separated by preparative TLC. $20.3 \mathrm{mg}$ of $\mathbf{5}$ were treated with $\mathrm{Ac}_{2} \mathrm{O} /$ pyridine $(1: 1)$ to afford $6\left(14.8 \mathrm{mg}, \mathrm{mp} 166-168{ }^{\circ} \mathrm{C}\right)$. The mother liquor (AM 5-8, $360.0 \mathrm{mg}$ ) was submitted to silica 
Table 2. ${ }^{13} \mathrm{C}$ NMR spectral data for glycoside moieties of $\mathbf{1 3}, \mathbf{1 4}$ and $\mathbf{1 6}$ in pyridine- $d_{5}(125 \mathrm{MHz}$ : $\mathbf{1 3}$ and $\mathbf{1 4} ; 50 \mathrm{MHz}$ : 16) and of peracetyl derivatives 15 and 17 in $\mathrm{CDCl}_{3}(125 \mathrm{MHz}) *$

\begin{tabular}{|c|c|c|c|c|c|}
\hline $\mathrm{C}$ & trisaccharide of $\mathbf{1 3}$ & trisaccharide of $\mathbf{1 4}$ & trisaccharide of $\mathbf{1 5}^{\mathrm{a}}$ & trisaccharide of $\mathbf{1 6}$ & trisaccharide of 17 \\
\hline $1^{\prime}(\mathrm{CH})$ & 100.6 & 100.3 & 99.8 & 100.4 & 99.6 \\
\hline $2^{\prime}(\mathrm{CH})$ & 78.2 & 77.8 & 76.5 & 76.6 & 73.1 \\
\hline $3^{\prime}(\mathrm{CH})$ & 78.3 & 78.1 & 75.5 & 84.9 & 78.3 \\
\hline $4^{\prime}(\mathrm{CH})$ & 79.0 & 78.8 & 77.9 & 70.5 & 69.5 \\
\hline $5^{\prime}(\mathrm{CH})$ & 77.3 & 76.9 & 72.5 & 77.5 & 70.9 \\
\hline $6^{\prime}\left(\mathrm{CH}_{2}\right)$ & 61.7 & 61.3 & 62.1 & 62.6 & 62.0 \\
\hline $1 "(\mathrm{CH})$ & 103.3 & 102.9 & 99.7 & 105.9 & 99.2 \\
\hline $2 ”(\mathrm{CH})$ & 72.9 & 72.5 & 70.5 & 72.6 & 71.8 \\
\hline $3 "(\mathrm{CH})$ & 73.1 & 72.8 & 68.8 & 80.2 & 72.3 \\
\hline $4 "(\mathrm{CH})$ & 74.3 & 73.9 & 70.8 & 75.2 & 68.2 \\
\hline $5 "(\mathrm{CH})$ & 70.8 & 70.5 & 68.1 & 77.5 & 72.0 \\
\hline $6 "\left(\mathrm{CH}_{3}\right)$ & 18.9 & 18.5 & 17.4 & 62.6 & 60.9 \\
\hline $1 " ”(\mathrm{CH})$ & 102.4 & 102.1 & 97.5 & 102.3 & 97.0 \\
\hline $2 ",(\mathrm{CH})$ & 72.9 & 72.6 & 70.2 & 72.9 & 68.9 \\
\hline $3 ", "(\mathrm{CH})$ & 73.1 & 72.9 & 68.8 & 74.2 & 69.1 \\
\hline $4 " ”(\mathrm{CH})$ & 74.5 & 74.2 & 71.5 & 75.0 & 70.9 \\
\hline $5^{\prime \prime \prime}(\mathrm{CH})$ & 69.9 & 69.5 & 66.7 & 69.5 & 66.5 \\
\hline $6 ",\left(\mathrm{CH}_{3}\right)$ & 19.0 & 18.7 & 17.5 & 18.7 & 17.1 \\
\hline
\end{tabular}

* Number of hydrogens bound to carbon atoms deduced by comparative analysis of $\left\{{ }^{1} \mathrm{H}\right\}$ - and DEPT- ${ }^{13} \mathrm{C}$ NMR spectra. $2 \mathrm{D}{ }^{1} \mathrm{H}-{ }^{1} \mathrm{H}-\mathrm{COSY}$ and ${ }^{1} \mathrm{H}-{ }^{13} \mathrm{C}-{ }^{\mathrm{n}} \mathrm{JCH}_{\mathrm{CH}}$ $\left(\mathrm{n}=2\right.$ and 3) NMR spectra were also used in these assignments; ${ }^{\mathrm{a}} \delta_{\mathrm{COCH}_{3}}: 169.9-170.9(\mathrm{CO}), 20.9-21.7\left(\mathrm{CH}_{3}\right)$.

gel CC and fractions 8-12 yielded a mixture of 8 and 9 $(1.2 \mathrm{mg}$, gum $)$. Fraction $10(850 \mathrm{mg})$ from col A was chromatographed on a silica gel column and 130 fractions of $50 \mathrm{~mL}$ were collected. Fractions $32-40$ yielded $35.5 \mathrm{mg}$ of a material corresponding to the mixture of $\mathbf{1 0}, \mathbf{1 1}$ and $\mathbf{1 2}$. Fractions 94-114 (102.3 mg) were chromatographed on a silica gel column and fractions 3-5 yielded $7(9.5 \mathrm{mg})$ after filtration on Sephadex LH20.

The green fruits ( $2.6 \mathrm{~g}$ ) of Solanum crinitum Lam were powdered and extracted with ethanol + acetic acid (2\%) and $900 \mathrm{~mL}$ of solution was obtained. $900 \mathrm{~mL}$ of acetic acid $(10 \%)$ were added, and the solution was left to stand and chill overnight. The solution was filtered under vacuum using Hirsch funnel. $\mathrm{NH}_{4} \mathrm{OH}$ (pH 9-10) was added to the filtrate which was allowed to stand overnight in the fridge affording a precipitate $(96.4 \mathrm{~g})$ corresponding to the glycoalkaloids fraction was obtained. $90 \mathrm{~g}$ of the glycoalkaloids was adsorbed on silica gel and applied on a silica gel column, eluted with hexane, dichloromethane, ethyl acetate, acetone and methanol. 14 fractions of $500 \mathrm{~mL}$ were collected. Fraction $8(1.0 \mathrm{~g})$, collected with ethyl acetate, was chromatographed in a silica gel CC and fractions analyzed by silica gel TLC plate. Fraction $84(52.6 \mathrm{mg})$ from this column was filtered on a Sephadex LH20 column, eluted with methanol, and the alkaloid solamargine $13\left(268-270^{\circ} \mathrm{C}\right)$ was obtained. Fraction
$10(8.67 \mathrm{~g})$ was extracted with methanol and the alkaloids were detected with Dragendorff and Libermann Burchard. This fraction was chromatographed on a silica gel column using $\mathrm{CH}_{2} \mathrm{Cl}_{2} / \mathrm{MeOH}$ (3:1) as initial eluent. 79 fractions were collected and were analyzed by TLC plate and reunited in group. Fractions 24-29 (1.2 g) were filtered on a Sephadex LH-20 column and the epi-solamargine $(\mathbf{1 4}, 225.8 \mathrm{mg}$, $\left.238-250{ }^{\circ} \mathrm{C}\right)$ was obtained. Acetic anhydride:pyridine (1:1) treatment of $14(44.5 \mathrm{mg})$ yielded $44.5 \mathrm{mg}$ of the peracetyl derivative 15 (mp 128-130 ${ }^{\circ} \mathrm{C}$ ). Fractions 39-44 (1.3 g) were filtered on Sephadex LH20 to isolate solasonine (16, $\left.93.5 \mathrm{mg}, \mathrm{mp} 244-246^{\circ} \mathrm{C}\right)$. Treatment of $\mathbf{1 6}(79.1 \mathrm{mg}$ ) with acetic anhydride:pyridine (1:1) gave the peracetyl-solasonine (17, $27.6 \mathrm{mg}$, mp $\left.148-150{ }^{\circ} \mathrm{C}\right)$.

\section{3,7,4'-trimethoxy-5-acethoxyflavone (6)}

Yellow powder, mp $166-168{ }^{\circ} \mathrm{C}$; IR $(\mathrm{KBr}) v_{\max } / \mathrm{cm}^{-1}$ : 1762, 1632, 1606, 1511; ${ }^{1} \mathrm{H}$ NMR $\left(\mathrm{CDCl}_{3}, 500 \mathrm{MHz}\right) \delta$ $6.60(\mathrm{~d}, J 2.5 \mathrm{~Hz}), 6.82(\mathrm{~d}, J 2.5 \mathrm{~Hz}), 8.02(\mathrm{dd}, J 9.0 \mathrm{~Hz})$, $7.02(\mathrm{~d}, J 9.0 \mathrm{~Hz}), 3.78,3.90$ (s), 3.89 (s), $2.47(\mathrm{~s}),{ }^{13} \mathrm{C} \mathrm{NMR}$ $\left(\mathrm{CDCl}_{3}, 125 \mathrm{MHz}\right) \delta 154.8(\mathrm{C}-2), 140.8(\mathrm{C}-3), 173.2(\mathrm{C}-4)$, 150.5 (C-5), 108.0 (CH-6), 163.1 (C-7), 98.6 (CH-8), 157.8 (C-9), 111.4 (C-10), 122.9 (C-1'), 129.9 (CH-2', 6'), 114.0 (CH-3',5'), 161.4 (C-4'), 59.9, 55.9, 55.3 (MeO-3,7,4', respectively), 169.7/21.2 $\left(\mathrm{COCH}_{3}-5\right)$. 
Table 3. ${ }^{1} \mathrm{H}$ NMR spectral data for aglycone of 13, 14 and 16 in pyridine- $d_{5}(500 \mathrm{MHz}$ : 13 and 14; $200 \mathrm{MHz}$ : 16) and of peracetyl derivatives 15 and $\mathbf{1 7}$ in $\mathrm{CDCl}_{3}(500 \mathrm{MHz})$. Chemical shifts in $\delta(\mathrm{ppm})$ and coupling constants $\left(J\right.$ in parentheses) in $\mathrm{Hz}^{*}$

\begin{tabular}{|c|c|c|c|c|c|}
\hline$\underline{\mathrm{H}}$ & 13 & 14 & $15^{\mathrm{a}}$ & 16 & $17^{\mathrm{a}}$ \\
\hline 1 & $1.73 / 1.00$ & $1.75 / 1.02$ & $1.85 / 1.08$ & & $1.85 / 1.08$ \\
\hline 2 & $2.10 / 1.87$ & $2.08 / 1.85$ & $1.93 / 1.58$ & & $1.95 / 1.25$ \\
\hline 3 & $3.89(\mathrm{~m})$ & $3.89(\mathrm{~m})$ & 3.60 & $3.93(\mathrm{~m})$ & $3.58(\mathrm{~m})$ \\
\hline 4 & $2.82 / 2.75$ & $\begin{array}{c}2.81(\mathrm{dd}, J 11.6 ; 3.1) \\
2.73(\mathrm{t}, J 11.6)\end{array}$ & $2.40 / 2.25$ & $2.87 / 2.76$ & $2.45 / 2.28$ \\
\hline 6 & 5.32 (br s) & 5.33 (br s) & $5.36(\mathrm{~m})$ & $5.30($ br s) & $5.38(\mathrm{~m})$ \\
\hline 7 & 1.90 & 1.85 & 1.94 & & $2.30 / 1.68$ \\
\hline 8 & 1.48 & 1.58 & 1.56 & & 1.53 \\
\hline 9 & 0.90 & $0.89(\mathrm{~m})$ & 0.95 & & 0.95 \\
\hline 11 & 1.45 & 1.42 & $1.55-1.45$ & & $1.55-1.45$ \\
\hline 12 & $1.63 / 1.05$ & $1.68 / 1.09$ & $2.08 / 1.25$ & & $2.08 / 1.25$ \\
\hline 14 & 1.10 & $1.09(\mathrm{~m})$ & 0.98 & & 0.98 \\
\hline 15 & $2.08 / 1.45$ & $2.08 / 1.48$ & $2.20 / 1.70$ & & $1.95 / 1.85$ \\
\hline 16 & 4.42 & 4.82 & 5.06 & 4.21 & 5.08 \\
\hline 17 & 1.78 & 2.02 & 1.53 & & 1.53 \\
\hline 18 & $0.88(\mathrm{~s})$ & $0.85(\mathrm{~s})$ & $0.87(\mathrm{~s})$ & $0.82(\mathrm{~s})$ & $0.91(\mathrm{~s})$ \\
\hline 19 & $1.07(\mathrm{~s})$ & $1.06(\mathrm{~s})$ & $1.01(\mathrm{~s})$ & $1.03(\mathrm{~s})$ & $1.04(\mathrm{~s})$ \\
\hline 20 & 1.98 & 2.14 & 2.10 & & 2.08 \\
\hline 21 & $1.09(\mathrm{~d}, J 6.9)$ & $1.28(\mathrm{~d}, J 6.7)$ & $1.26(\mathrm{~d}, J 6.9)$ & $1.17(\mathrm{~d})$ & $1.26(\mathrm{~d}, J 7.0)$ \\
\hline 23 & $1.90 / 1.65$ & $1.92 / 1.78$ & $2.36 / 1.04$ & & $2.35 / 1.03$ \\
\hline 24 & 1.52 & 1.65 & $2.28 / 1.68$ & & $1.70 / 1.65$ \\
\hline 25 & 1.65 & 1.58 & 2.02 & & 2.02 \\
\hline 26 & 2.78 & $3.04(\mathrm{~m}) / 2.89(\mathrm{t}, J 11.5)$ & 3.20 & 2.83 & $3.16(\mathrm{~m})$ \\
\hline 27 & $0.83(\mathrm{~d}, J 4.8)$ & $0.79(\mathrm{~d}, J 6.5)$ & $0.92(\mathrm{~d}, J 6.6)$ & $0.76(d)$ & $0.93(\mathrm{~d}, J 7.5)$ \\
\hline
\end{tabular}

"Number of hydrogens bound to carbon atoms deduced by comparative analysis of $\left\{{ }^{1} \mathrm{H}\right\}$ - and DEPT- ${ }^{13} \mathrm{C}$ NMR spectra. Chemical shifts and coupling constants ( $J$, in parentheses) obtained from $1 \mathrm{D}{ }^{1} \mathrm{H}$ NMR spectra. $2 \mathrm{D}{ }^{1} \mathrm{H}-{ }^{1} \mathrm{H}-\mathrm{COSY}$ and ${ }^{1} \mathrm{H}-{ }^{13} \mathrm{C}_{-}{ }^{\mathrm{n}} \mathrm{CH}_{\mathrm{CH}}(\mathrm{n}=2$ and 3) NMR spectra were also used in these assignments; ${ }^{\mathrm{a}} \delta_{\mathrm{COCH}_{3}}: 2.16(\mathrm{~s})$.

\section{Epi-solamargine (14)}

Colorless crystals, mp $238-250{ }^{\circ} \mathrm{C} ;[\alpha]^{25}{ }_{\mathrm{D}}-98(c 0.1$, $\mathrm{MeOH}$ ); IR (KBr) $v_{\max } / \mathrm{cm}^{-1}: 3417,2927,1453,1384$, $1044 \mathrm{~cm}^{-1}$. HR-FABMS positive ions at $\mathrm{m} / z 868.5239$ $[\mathrm{M}+\mathrm{H}]^{+}$(calc. for $\mathrm{C}_{45} \mathrm{H}_{74} \mathrm{NO}_{15}: \mathrm{m} / 2$ 868.505846), 722.4643 (calc. for $\mathrm{C}_{39} \mathrm{H}_{64} \mathrm{NO}_{11}:$ 722.447937) [M+H-rhamnose], $m / z 576.4037$ (calc. for $\left.\mathrm{C}_{33} \mathrm{H}_{54} \mathrm{NO}_{7}: 576.390028\right)[\mathrm{M}+\mathrm{H}-$ rhamnose-rhamnose $]^{+}, \mathrm{m} / \mathrm{z} 445.7553$ (calc. for $\mathrm{C}_{21} \mathrm{H}_{33} \mathrm{O}_{10}$ : 445.207372) [M-423] $]^{+}, m / z 414.3467$ (calc. for $\mathrm{C}_{27} \mathrm{H}_{44} \mathrm{NO}_{2}$ : 414.337204) [M+H-rhamnose-rhamnose-glucose ${ }^{+}, \mathrm{m} / \mathrm{z}$ 413.2782 (calc. for $\mathrm{C}_{27} \mathrm{H}_{43} \mathrm{NO}_{2}: 413.329379$ ) [M-rhamnoserhamnose-glucose $]+{ }^{+}{ }^{13} \mathrm{C}$ RMN: Tables 1 and $2 .{ }^{1} \mathrm{H}$ RMN: Tables 3 and 4 .

\section{Peracetyl-epi-solamargine (15)}

Crystal, mp $128-130{ }^{\circ} \mathrm{C},[\alpha]^{25}-165(c 0.1, \mathrm{MeOH})$; IR (KBr) $v_{\max } / \mathrm{cm}^{-1}$ : 2943. 2728, 1751, 1438, 1374, 1045; Positive ion FABMS m/z $1246.5522[\mathrm{M}+\mathrm{H}]^{+}$(calc. for
$\mathrm{C}_{63} \mathrm{H}_{92} \mathrm{NO}_{24}:$ 1246.600928), $\mathrm{m} / \mathrm{z} 1204.5278$ (calc. for $\left.\mathrm{C}_{61} \mathrm{H}_{90} \mathrm{NO}_{23}: 1204.590364\right)[\mathrm{M}+\mathrm{H}-42]^{+}, \mathrm{m} / z$ 974.5256 (calc. for $\mathrm{C}_{51} \mathrm{H}_{76} \mathrm{NO}_{17}$ : 974.511325) [M+H-rhamnose $]^{+}, \mathrm{m} / \mathrm{z}$ 932.5163 (calc. for $\mathrm{C}_{49} \mathrm{H}_{74} \mathrm{NO}_{16}: 932.500760$ ) [M-314] ${ }^{+}, \mathrm{m} / \mathrm{z}$ 634.7963 (calc. for $\mathrm{C}_{39} \mathrm{H}_{56} \mathrm{NO}_{6}: 634.410763$ ) [M+H-612] $\mathrm{m} / \mathrm{z} 413.2715$ (calc. for $\mathrm{C}_{27} \mathrm{H}_{43} \mathrm{NO}_{2}: 413.329379$ ) [M-acetate-rhamnose-rhamnose-glucose ${ }^{+} .{ }^{13} \mathrm{C}$ RMN: Tables 1 and 2. ${ }^{1} \mathrm{H}$ RMN: Tables 3 and 4.

\section{Peracetyl-solasonine (17)}

Crystal, mp 148-150 ${ }^{\circ} \mathrm{C} ;{ }^{13} \mathrm{C}$ RMN: Tables 1 and 2; ${ }^{1} \mathrm{H}$ RMN: Tables 3 and 4.

\section{Supplementary Information}

Supplementary data associated with this paper are available free of charge at http://jbcs.sbq.org.br, as a PDF file including a molecular modeling study in order to 
Table 4. ${ }^{1} \mathrm{H}$ NMR spectral data for glycoside moieties of 13, 14 and $\mathbf{1 6}$ in pyridine- $d_{5}$ (500 MHz: $\mathbf{1 3}$ and 14; $200 \mathrm{MHz}$ : 16) and of peracetyl derivatives 15 and 17 in $\mathrm{CDCl}_{3}(500 \mathrm{MHz})$. Chemical shifts in $\delta(\mathrm{ppm})$ and coupling constants $\left(J\right.$ in parentheses) in $\mathrm{Hz}^{*}$

\begin{tabular}{|c|c|c|c|c|c|}
\hline $\mathrm{H}$ & Glycoside unit of $\mathbf{1 3}$ & Glycoside unit of $\mathbf{1 4}$ & Glycoside unit of $\mathbf{1 5}^{\mathrm{a}}$ & Glycoside unit of $\mathbf{1 6}$ & Glycoside unit of $\mathbf{1 7 ^ { a }}$ \\
\hline 1 ' & 4.95 & 4.96 & $4.56(\mathrm{~d}, J 7.7)$ & 4.95 & $4.46(\mathrm{~d}, J 8.0)$ \\
\hline $2^{\prime}$ & 4.24 & 4.22 & 3.56 & 3.98 & $3.84(\mathrm{dd}, J 8.0 ; 9.5)$ \\
\hline 3 & $4.23(\mathrm{t})$ & 4.23 & $5.28(\mathrm{t}, J 9.4)$ & $4.33(\mathrm{~m})$ & $3.91(\mathrm{dd}, J 9.5 ; 3.0)$ \\
\hline 4, & $4.42(\mathrm{t})$ & 4.40 & $3.73(\mathrm{t}, J 9.4)$ & 4.82 & $5.26(\mathrm{br} \mathrm{s})$ \\
\hline 5 , & $3.65(\mathrm{br} \mathrm{d}, J 9.2)$ & $3.66(\mathrm{td}, J 9.2)$ & $3.59(\mathrm{~m})$ & & $3.79(\mathrm{~m})$ \\
\hline 6 & $\begin{array}{l}4.22(\mathrm{br} \mathrm{d}, J 12.0) \\
4.10(\mathrm{br} \mathrm{d}, J 12.0)\end{array}$ & $\begin{array}{c}4.23(\mathrm{dd}, J 12.1 ; 3.2) \mathrm{n} \\
4.10(\mathrm{dd}, J 12.1 ; 3.2)\end{array}$ & $\begin{array}{c}4.44(\mathrm{~d}, J 12.3) \\
4.28(\mathrm{dd}, J 12.3 ; 3.6)\end{array}$ & & $\begin{array}{l}4.12(\mathrm{~m}) \\
4.06(\mathrm{~m})\end{array}$ \\
\hline $1 "$ & $5.86(\mathrm{~s})$ & $5.87(\mathrm{~s})$ & $4.79(\mathrm{~d}, J 1.5)$ & $5.17(\mathrm{~d})$ & $4.71(\mathrm{~d}, J 8.0)$ \\
\hline $2 "$ & $4.69(\mathrm{sl})$ & $4.69(\mathrm{~d}, J 1.4)$ & $5.02(\mathrm{~m})$ & $4.68(\mathrm{sl})$ & $4.85(\mathrm{dd})$ \\
\hline $3 "$ & $4.55(\mathrm{dd}, J 9.1 ; 2.9)$ & $4.55(\mathrm{dd}, J 9.2 ; 3.2)$ & $5.16(\mathrm{dd}, J 10.2 ; 3.1)$ & & $5.22(\mathrm{t})$ \\
\hline $4 "$ & 4.38 & $4.34(\mathrm{t}, J 9.2)$ & $5.03(\mathrm{t}, J 10.2)$ & & 5.08 \\
\hline $5 "$ & 4.92 & $4.93(\mathrm{~m})$ & $3.85(\mathrm{~m})$ & & $3.69(\mathrm{~m})$ \\
\hline $6 "$ & $1.64(\mathrm{~d}, J 5.9)$ & $1.64(\mathrm{~d}, J 6.1)$ & $1.14(\mathrm{~d}, J 6.1)$ & & $4.38(\mathrm{br} \mathrm{d}, J 10.5) / 4.10$ \\
\hline $1 "$, & $6.41(\mathrm{~s})$ & $6.41(\mathrm{~s})$ & $4.90(\mathrm{~d}, J 1.5)$ & $6.28(\mathrm{~s})$ & $5.02(\mathrm{sl})$ \\
\hline $2 "$, & 4.84 (br s) & $4.84(\mathrm{~d}, J 1.8)$ & $5.00(\mathrm{~m})$ & $4.90(\mathrm{~d})$ & 5.22 \\
\hline $3 " ”$ & $4.64(\mathrm{dd}, J 9.1 ; 2.9$ & $4.64(\mathrm{dd}, J 9.2 ; 3.3)$ & $5.23(\mathrm{dd}, J 10.1 \mathrm{~Hz} ; 3.1)$ & 4.61 & 5.22 \\
\hline $4 "$, & 4.34 & $4.32(\mathrm{t}, J 9.2)$ & $5.05(\mathrm{t}, J 10.1)$ & & $5.02(\mathrm{~m})$ \\
\hline $5 "$ & 4.96 & $4.98(\mathrm{~m})$ & $4.36(\mathrm{~m})$ & 4.88 (br s) & $4.43(\mathrm{~m})$ \\
\hline $6 "$ & $1.78(\mathrm{~d}, J 6.0)$ & $1.78(\mathrm{~d}, J 6.2)$ & $1.17(\mathrm{~d}, J 6.2)$ & $1.78(\mathrm{~d})$ & $1.19(\mathrm{~d}, J 6.0)$ \\
\hline
\end{tabular}

*Number of hydrogen bound to carbon atoms deduced by comparative analysis of $\left\{{ }^{1} \mathrm{H}\right\}$ - and DEPT- ${ }^{13} \mathrm{C}$ NMR spectra. Chemical shifts and coupling constants $\left(J\right.$, in parentheses) obtained from $1 \mathrm{D}{ }^{1} \mathrm{H}$ NMR spectra. $2 \mathrm{D}{ }^{1} \mathrm{H}-{ }^{1} \mathrm{H}-\mathrm{COSY}$ and ${ }^{1} \mathrm{H}-{ }^{13} \mathrm{C}-{ }^{\mathrm{n}} J_{\mathrm{CH}}(\mathrm{n}=2$ and 3) NMR spectra were also used in these assignments; ${ }^{\mathrm{a}} \delta_{\mathrm{COCH}_{3}}: 1.98-2.15\left(8 \times \mathrm{CH}_{3}\right)$.

compare the relative stabilities of the epimeric structures 13 and 14.

\section{Acknowledgments}

The authors are grateful to CNPq, FAPERJ and CAPES for research fellowships and financial support. They also thank CENAUREMN for the $500 \mathrm{MHz}$ NMR spectra, Laboratório Plataforma de Métodos Analíticos de Farmanguinhos/FIOCRUZ for the $400 \mathrm{MHz}$ NMR spectra. They thank MSc J.M. Alves and Dr. M. de F. Agra for the collection and classification of plant material.

\section{References}

1. Agra, M. F.; Novon 1999, 9, 292.

2. Fukuhara, K.; Shimizu, K.; Kubo, I.; Phytochemistry 2004, 65, 1283.

3. Alves, C. C. F.; Alves, J. M.; Silva, T. M. S.; Carvalho, M. G. de; Neto, J. J.; Floresta e Ambiente 2003, 10, 93.

4. Silva, T. M. S.; Câmara, C. A.; Agra, M. F.; Carvalho, M. G. de; Frana, M. T.; Brandoline, S. V. P. B.; Paschoal, L. S.; BrazFilho, R.; Fitoterapia 2006, 77, 449.
5. Mola, J. L.; Araujo, E. R.; Magalhães, G. C.; Quim. Nova 1997, $20,460$.

6. D'arcy, W. G. In The Biology and Taxonomy of the Solanaceae; Hawkes, J. G.; Lester, R. N.; Skelding, A., eds., Academic Press: London, 1979, pp. 3-49.

7. Steinharter, T. P.; Cooper-Driver, G. A.; Anderson, G. J.; Biochem. Syst. Ecol. 1986, 14, 299.

8. Silva, T. M. S.; Carvalho, M. G. de; Braz-Filho, R.; Agra, M. F.; Quim. Nova 2003, 26, 517.

9. Agra, M. F.; PhD Thesis, Universidade de São Paulo, Brazil, 2000.

10. Dias-Filho, M. B.; Pesq. Agropec. Bras. 1997, 32, 789.

11. Silva, T. M. S.; Nascimento, R. J. B.; Câmara, C. A.; Castro, R. N.; Braz-Filho, R.; Agra, M. de F.; Carvalho, M. G. de; Biochem. Syst. Ecol. 2004, 32, 513.

12. Silva, T. M. S. da; Braz-Filho, R.; Carvalho, M. G. de; Agra, M. de F.; Biochem. Syst. Ecol. 2002, 30, 1083.

13. Silva, T. M. S. da; Silva, C. de C.; Braz-Filho, R.; Carvalho, M. G. de; Agra, M. de F.; Rev. Bras. Farmacogn. 2002, 12, 85.

14. Souza, A. E.; Silva, T. M. S. da; Alves, C. C. F.; Carvalho, M. G. de; Braz-Filho, R.; Echevarria, A.; J. Braz. Chem. Soc. 2002, 13,838 .

15. Markham, K. R. In Methods in Plant Biochemistry; Harborne, J. B.; Mabry, T. J., eds., Academic Press: London, 1989, p. 197. 
16. Kaouadji, M.; Phytochemistry 1990, 29, 2295.

17. Agrawal, P. K.; Bansal, M. C. In Carbon-13 NMR of Flavonoids, Studies in Organic Chemistry; Elsevier: Amsterdam, 1989, p. 362.

18. Markham, K. R.; Geiger, H. In The Flavonoids Advances in Research Since 1986; Harborne, J. B., ed., Chapman \& Hall: London, 1994, pp. 441.

19. Dong, H. Y.; Gou, L.; Cao, S. G.; Chen, S. X.; Sim, K. Y.; Goh, S. H.; Kini, R. M.; Phytochemistry 1999, 50, 899.

20. Mathias, L.; Vieira, I. J. C.; Braz-Filho, R.; Rodrigues-Filho, E. A.; J. Nat. Prod. 1998, 61, 1158.

21. Silva, V. C. da; Carvalho, M. G. de; Silva, S. L. da C. e; Rev. Latinoam. Quim. 2007, 35, 13.

22. Marin, J. C.; Torres, F.; Rev. Lationoam. Quim. 2001, 29, 100.

23. Rasmussen, S.; Wolff, C.; Rudolph, H.; Phytochemistry 1996, 42,81 .

24. Silva, A. M. S.; Alkorta, I.; Elguero, J.; Silva, V. L. M.; J. Mol. Struct. 2001, 595, 1.
25. Scott, K. N.; J. Am. Chem. Soc. 1972, 94, 8564.

26. Ripperger, H.; Phytochemistry 1995, 39, 1475.

27. Lorey, S.; Porzel, A.; Ripperger, H.; Phytochemistry 1996, 41, 1633.

28. Wanyonyi, A. W.; Chiabra, S. C.; Mkoji, G.; Eilert, U.; Njue, W. M.; Phytochemistry 2002, 59, 79.

29. Weissenberg, M.; Phytochemistry 2001, 58, 501.

30. Usubillaga, A.; Aziz, I.; Tettamanzi, M. C.; Waibel, R.; Phytochemistry 1997, 44, 537.

31. Lee, C.; Yang, W.; Parr, R. G.; Phys. Rev. B: Condens. Matter Mater. Phys. 1988, 37, 785.

32. Carvalho, M. G. de; Silva, V. C. da; Silva, T. M. S. da; Câmara, C. A.; Braz-Filho, R.; An. Acad. Bras. Cienc. 2009, 81, 21.

Submitted: March 23, 2009 Published online: August 12, 2010

FAPESP has sponsored the publication of this article. 


\section{Other Chemical Constituents Isolated from Solanum crinitum Lam. (Solanaceae)}

Marli T. F. Cornelius, ${ }^{a}$ Mário G. de Carvalho, ${ }^{*}, a$ Tania M. S. da Silva, ${ }^{a}$ Cassia C. F. Alves, ${ }^{a}$ Ana P. N. Siston, ${ }^{a}$ Kelly Z. Alves, ${ }^{a}$ Carlos M. R. Sant'Anna, ${ }^{a}$ Mario B. Neto, ${ }^{b}$ Marcos N. Eberlin ${ }^{b}$ and Raimundo Braz-Filho ${ }^{c}$

a Departamento de Química, ICE, Universidade Federal Rural do Janeiro, BR 465 km 07, 23890-000 Seropédica-RJ, Brazil

${ }^{b}$ Instituto de Química, Universidade Estadual de Campinas, 13084-862 Campinas-SP, Brazil

'Setor de Química de Produtos Naturais, LCQUI, CCT, Universidade Estadual do Norte Fluminense Darcy Ribeiro, 28013-602 Campos dos Goytacazes-RJ, Brazil

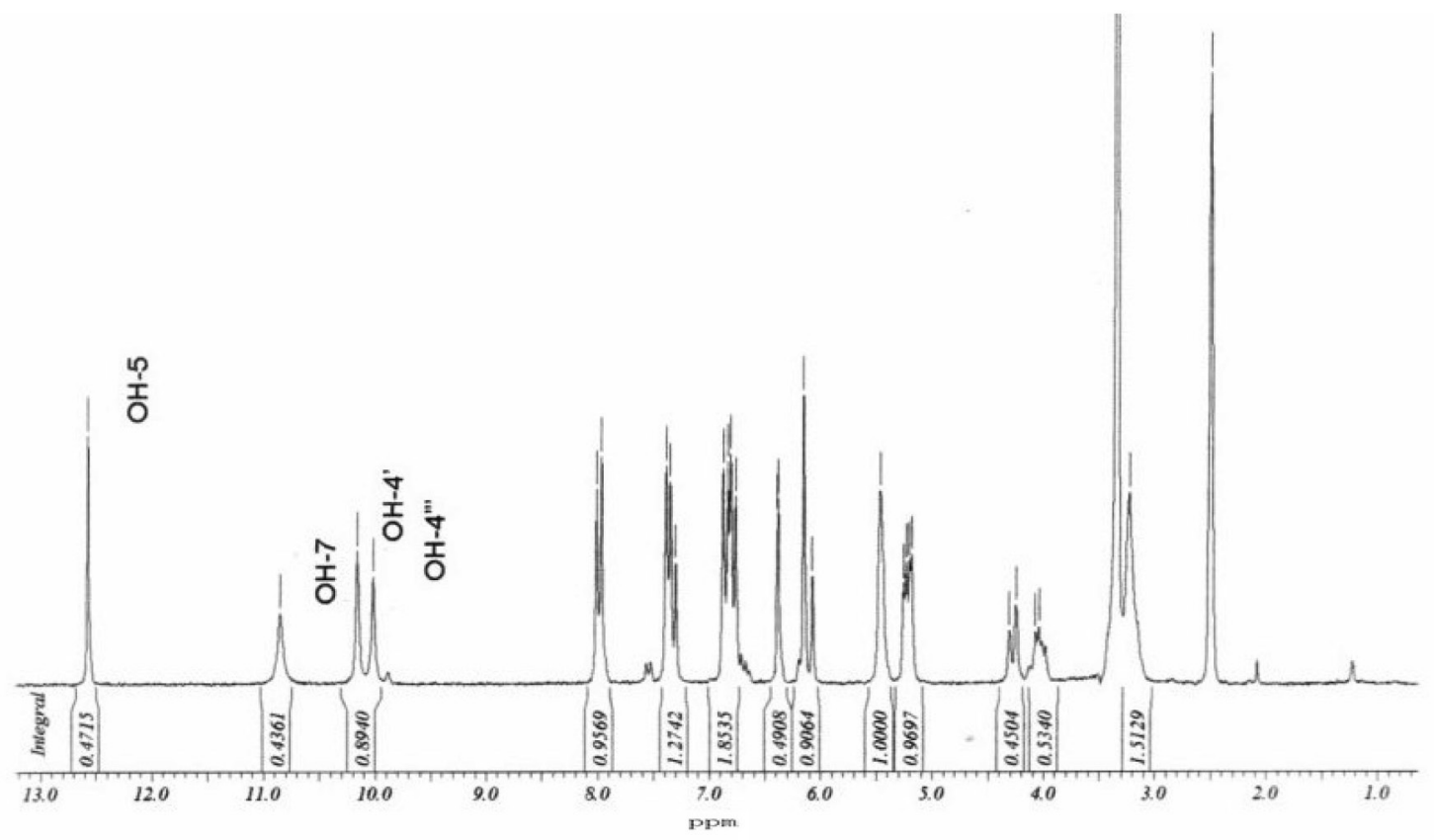

Figure S1. ${ }^{1} \mathrm{H}$ NMR spectrum of compound $\mathbf{1}$. 


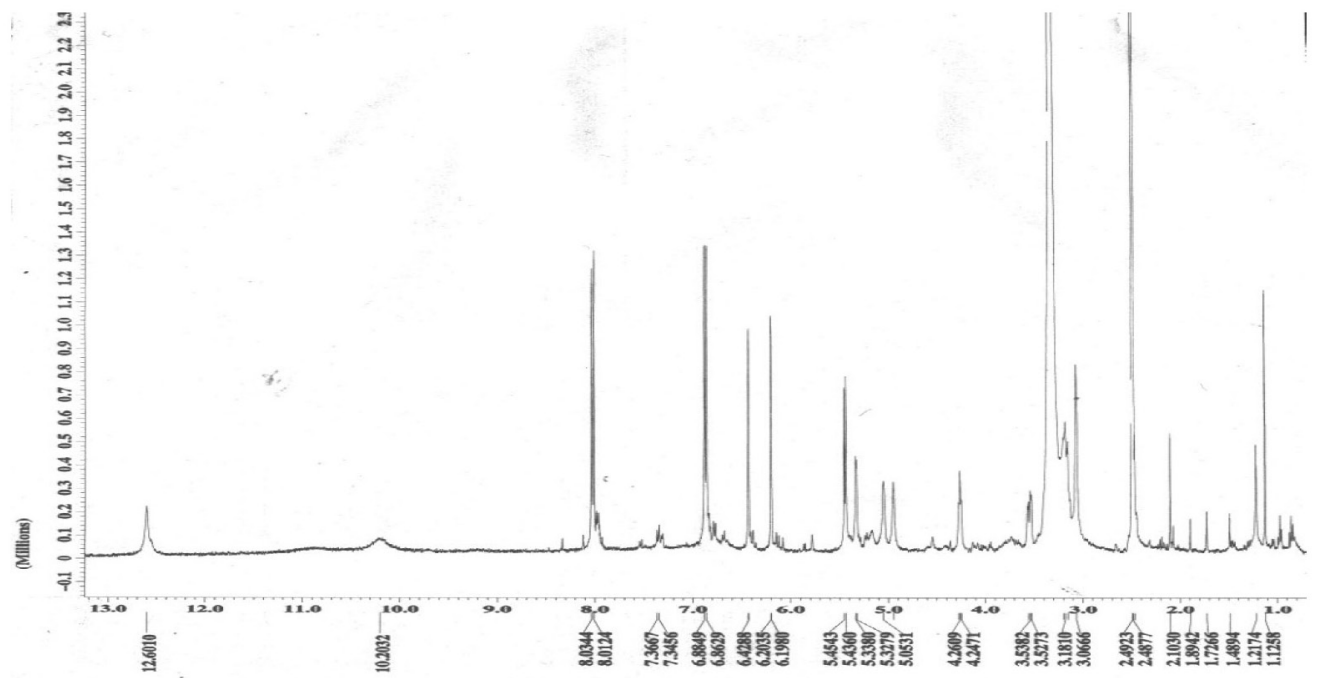

Figure S2. 'H NMR spectrum of compound 2.

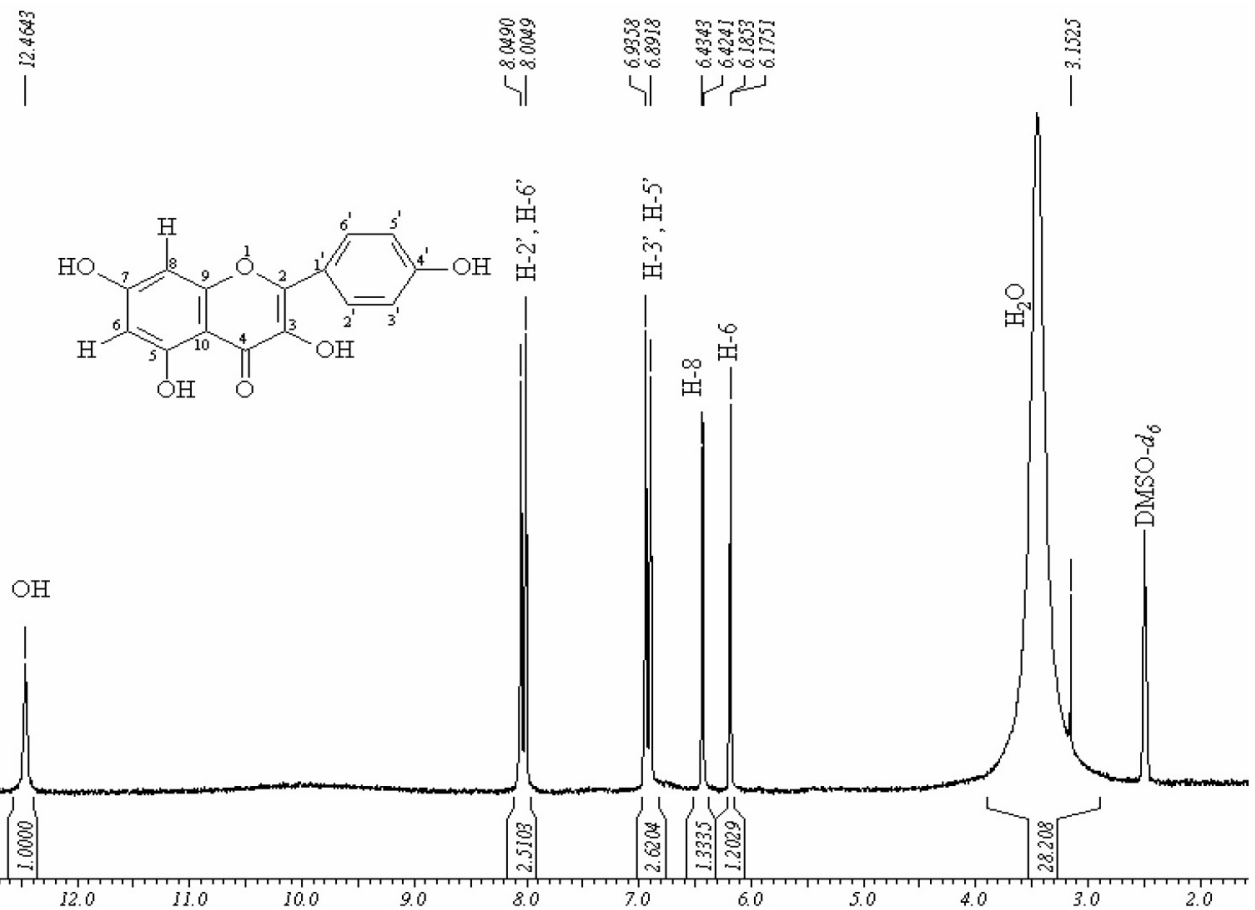

Figure S3. ${ }^{1} \mathrm{H}$ NMR spectrum of compound 3. 


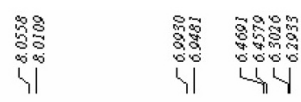

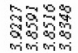<smiles></smiles>

誌

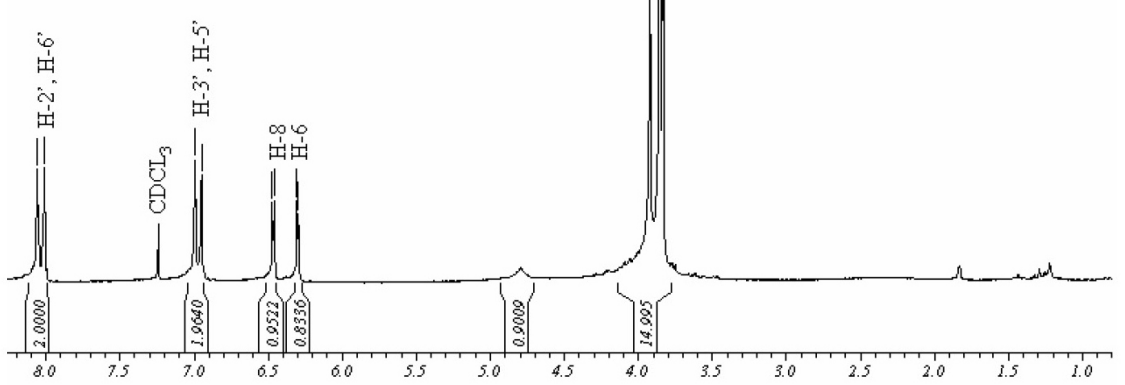

Figure S4. ${ }^{13} \mathrm{C}$ NMR spectrum of compound 4 .

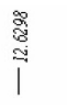<smiles>COc1ccc(-c2oc3cc(OC)c(OC)c(=O)c-3c(O)c2OC)cc1</smiles>
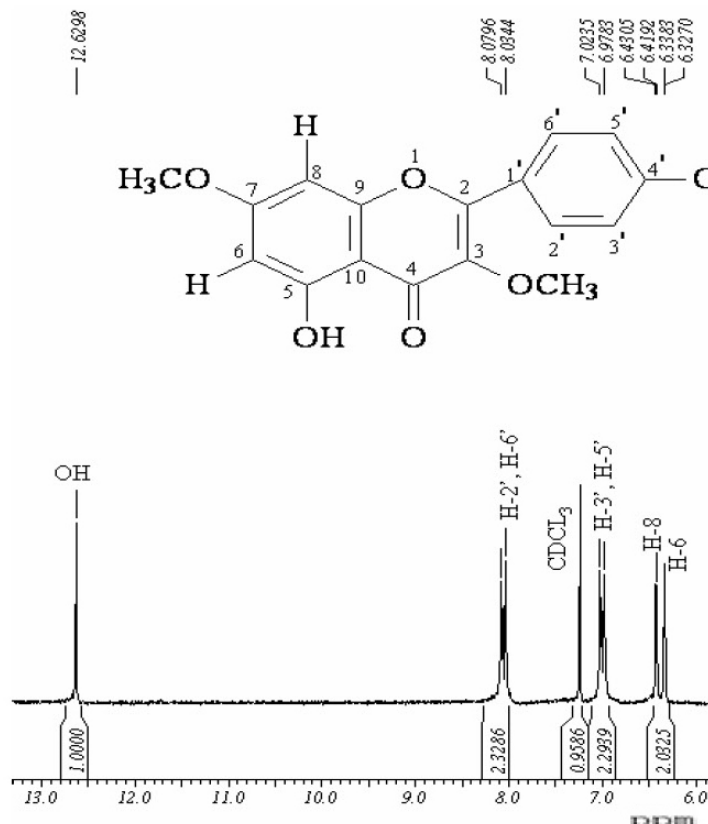

虽出
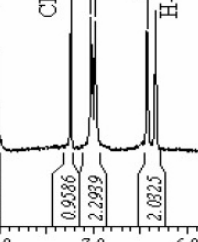

7.060

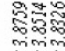

s.m.

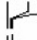

剾

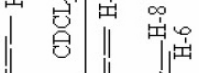

i

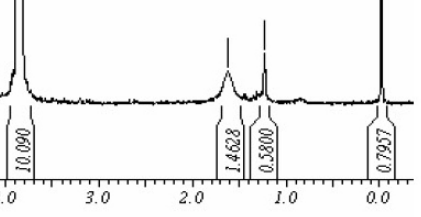

Figure S5. ${ }^{1} \mathrm{H}$ NMR spectrum of compound 5. 


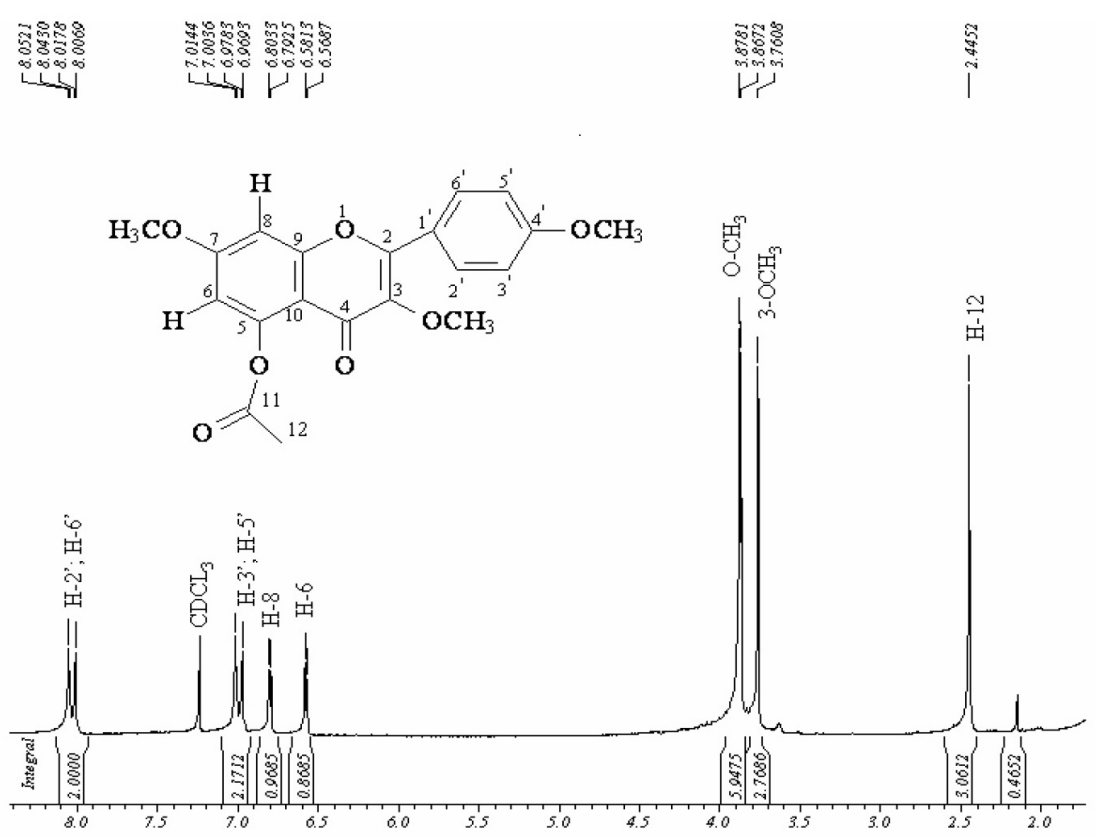

Figure S6. ${ }^{1} \mathrm{H}$ NMR spectrum of compound 6 .

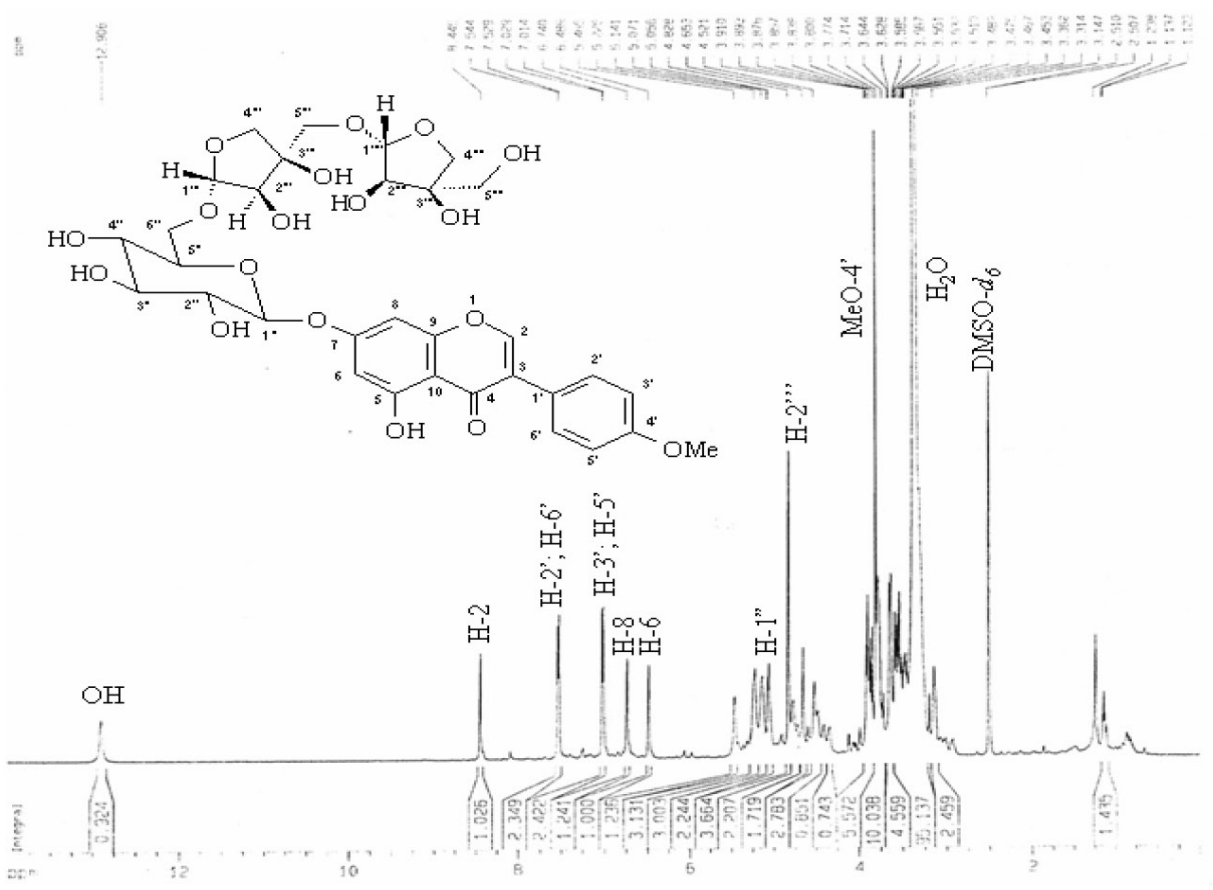

Figure S7. ${ }^{1} \mathrm{H}$ NMR (500 MHz) of compound 7. 


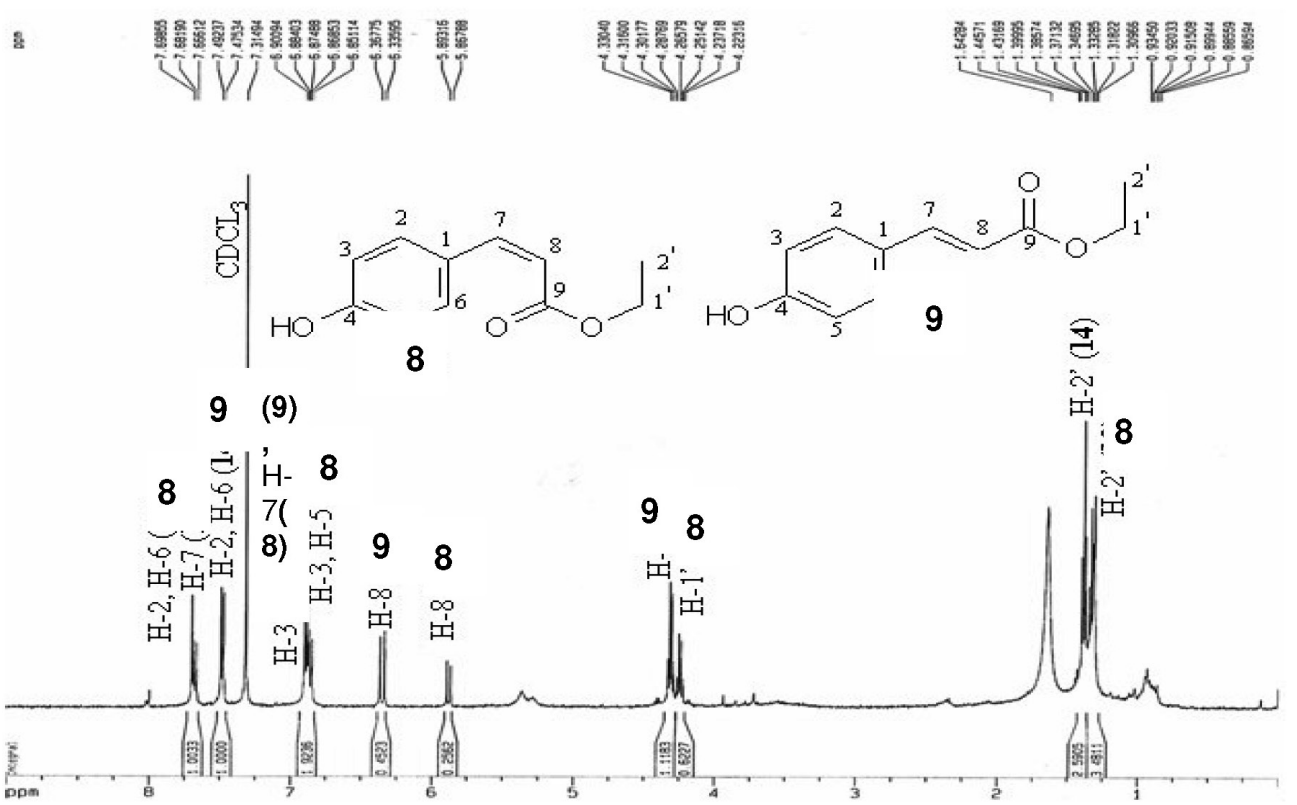

Figure S8. ${ }^{1} \mathrm{H}$ NMR spectrum(500 MHz) of compounds $8+9$.
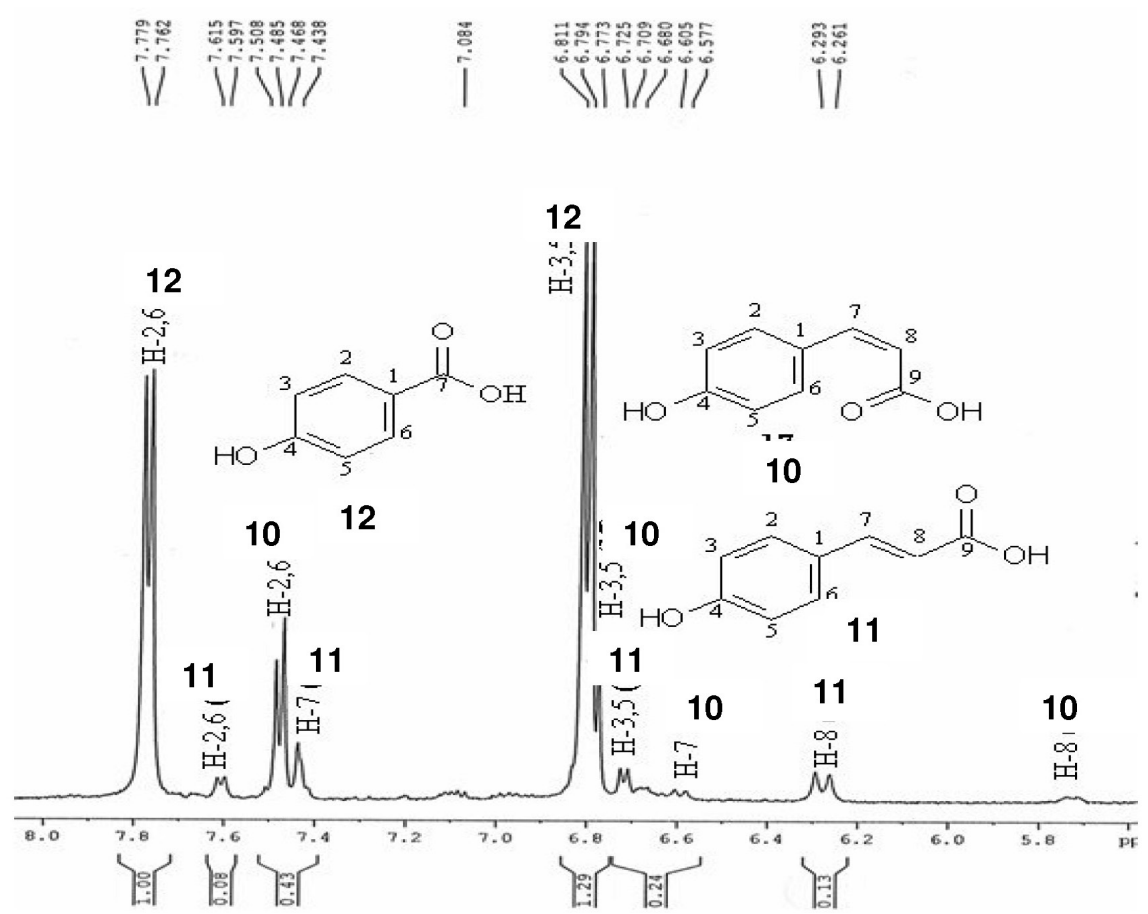

Figure S9. ${ }^{1} \mathrm{H}$ NMR spectrum $(500 \mathrm{MHz})$ of compounds $\mathbf{1 0 + 1 1 + 1 2}$. 


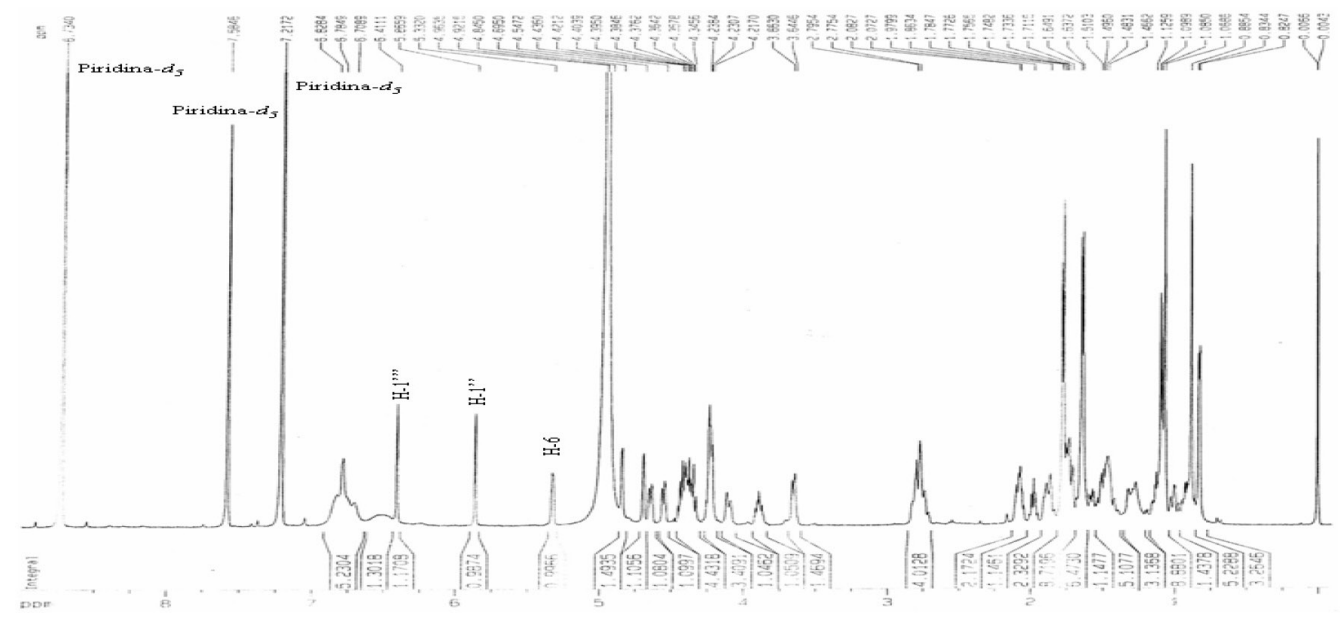

Figure S10. ${ }^{1} \mathrm{H}$ NMR spectrum $\left(500 \mathrm{MHz}\right.$, Pyridine- $d_{5}$ ) of the compound 13.

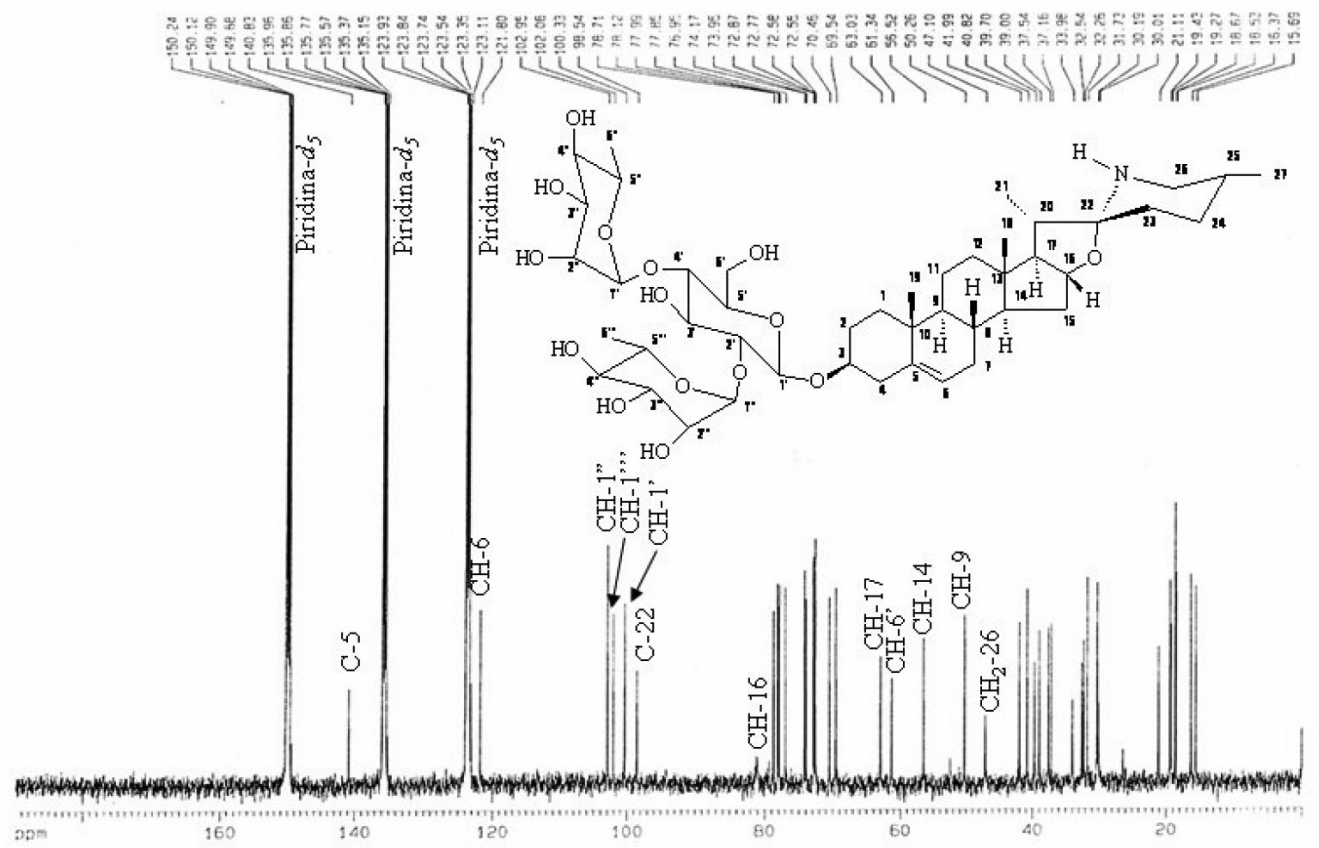

Figure S11. ${ }^{13} \mathrm{C}$ NMR (125 MHz) of compound 14. 


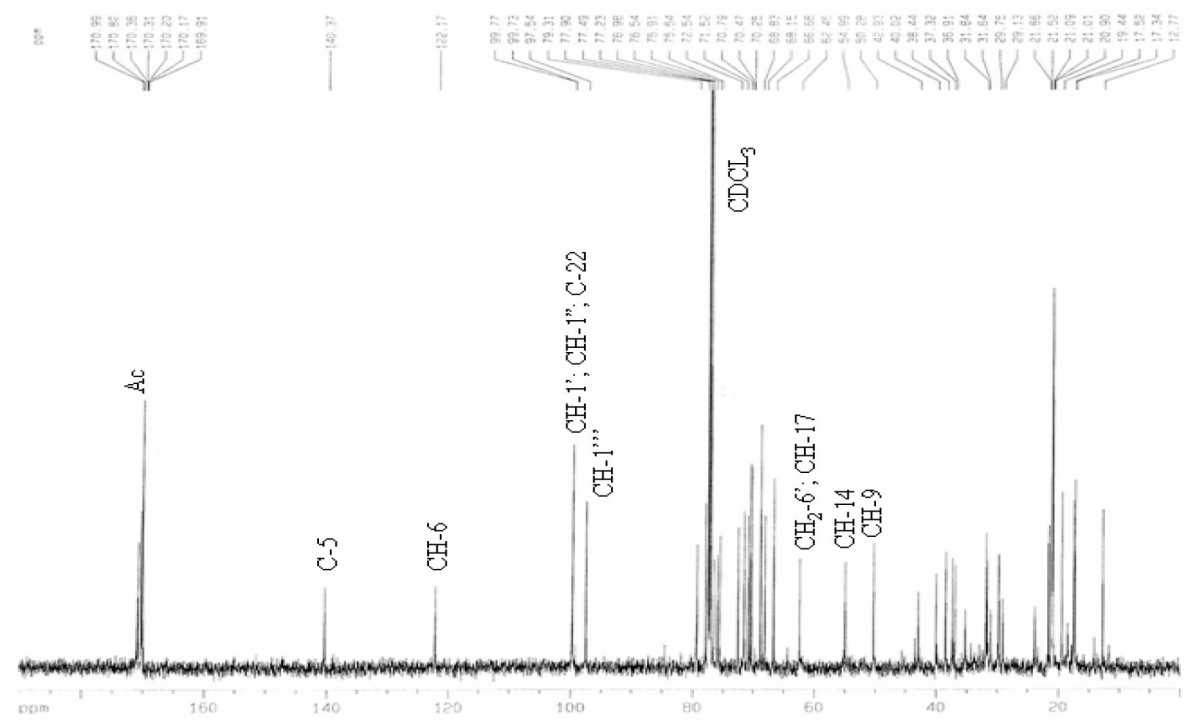

Figure S12. ${ }^{13} \mathrm{C}$ NMR spectrum $(125 \mathrm{MHz})$ of compound 15.

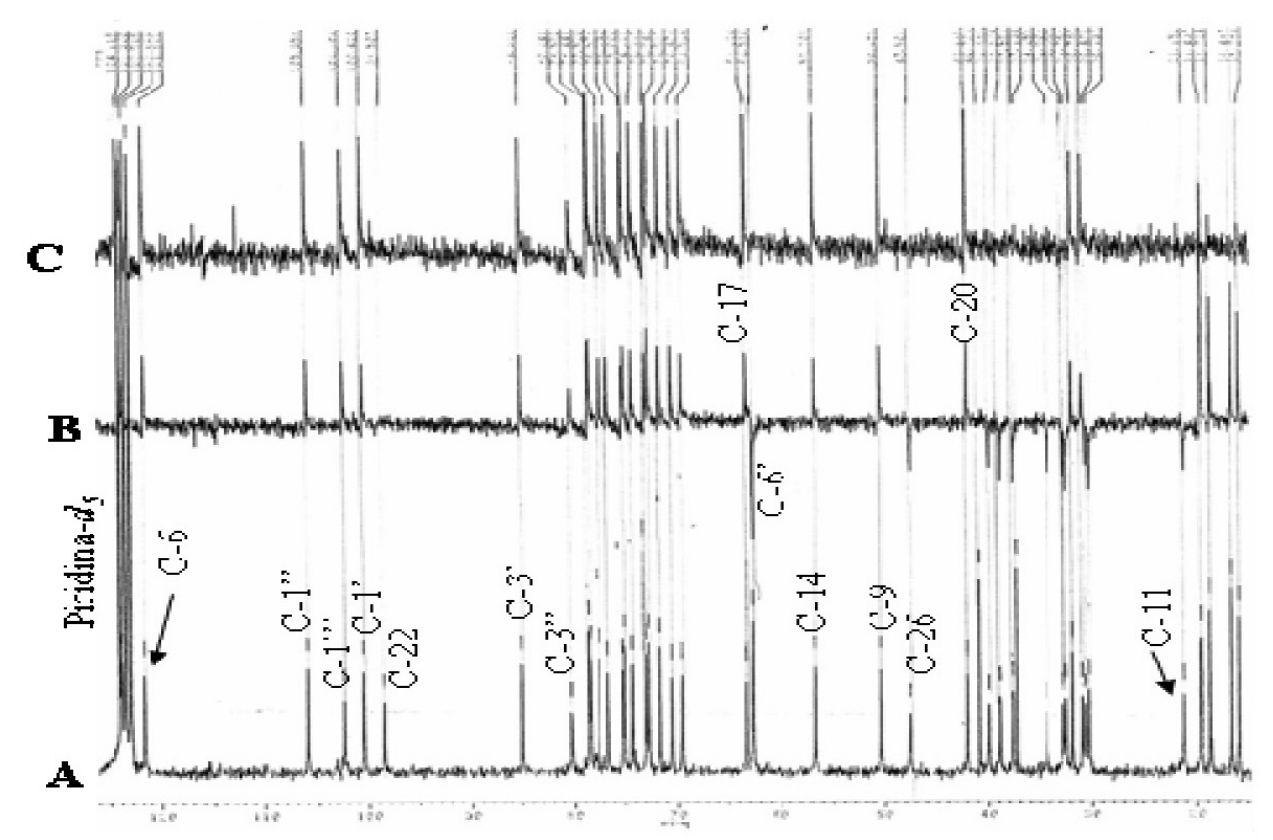

Figure S13. ${ }^{13} \mathrm{C}$ NMR spectrum BBD (A) and DEPT-135 ((B and C), $50 \mathrm{MHz}$, pyridine- $d_{6}$ ) of $\mathbf{1 6}$. 
(b)
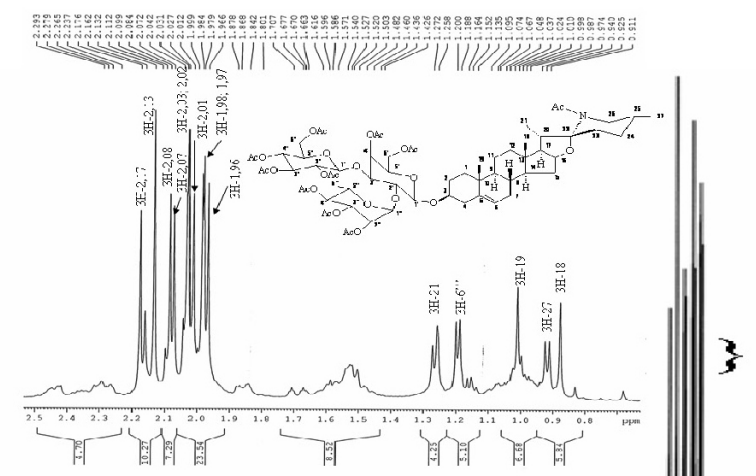

(a)

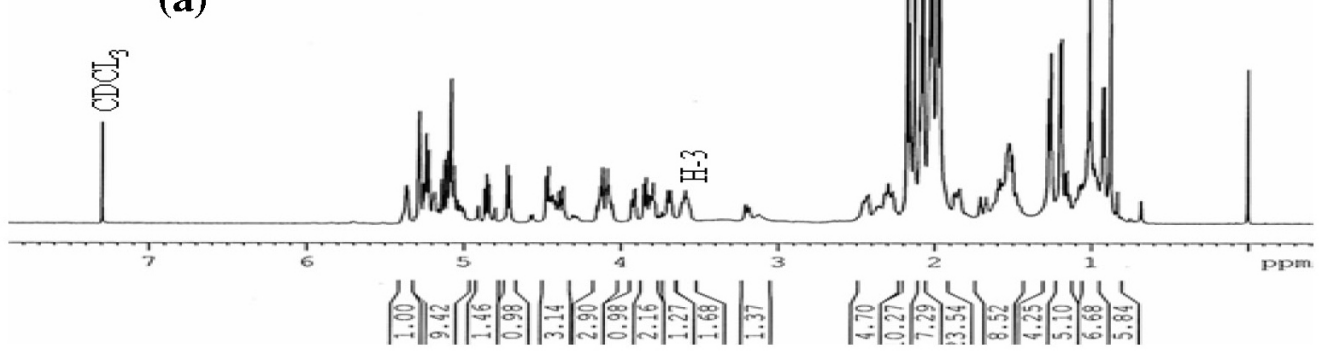

Figure S14. ${ }^{1} \mathrm{H}$ NMR spectrum (a) and expansion (b) (400 $\mathrm{MHz}, \mathrm{CDCl}_{3}$ ) of 17.

\section{Molecular Modeling}

In order to compare the relative stabilities of the epimeric structures $\mathbf{1 3} / \mathbf{1 4}$, a molecular modeling study was implemented using the Spartan 06 for Linux program (Wavefunction, Inc.). Because the long chain attached to C-3 should only have a small influence on the relative stabilities, it was replaced by a methoxy group to reduce the computational cost for the calculations. The conformer distribution of the resulting alpha and beta epimer models (13a and 14a) was determined with the Monte Carlo approach using the MMFF molecular mechanics force field. The most stable conformers of 13a and 14a were submitted to a previous energy minimization with the PM3 semi empirical method. ${ }^{31}$ The PM3 optimized structures were then submitted to a complete energy minimization with the B3LYP/6-31G* DFT method. The B3LYP method was chosen because it usually yields results for many properties in close agreement with those obtained from
MP calculations, and is more efficient than conventional $a b$ initio correlated methods for larger-scale calculations. The possibility of existence of this epimer as a stable species was verified by a molecular modeling study at the DFT B3LYP/6-31G* level with models of both epimers. The $\beta$-epimer model at C-20 (14a) is less stable than the $\alpha$-epimer one (13a), but the energy difference between both structures is only $4.85 \mathrm{kcal} \mathrm{mol}^{-1}\left(20.30 \mathrm{~kJ} \mathrm{~mol}^{-1}\right)$, as calculated with the B3LYP/6-31G* DFT method. Because of this small energy difference, the $\beta$-epimer is expected to exist in appreciable amount in an equilibrium mixture with the more stable $\alpha$-epimer. The main reason for the lower stability of the $\beta$-epimer should be the proximity between the C-21 methyl group and carbons C-23 and C-18. The corresponding C-C distances, which are equal to $4.22 \AA$ and $3.47 \AA$, respectively, in 13a, are considerably shorter in 14a, $3.43 \AA$ and $2.98 \AA$, respectively. This closer proximity would raise more unfavorable steric interactions in 14a than in 13a (Figure S15). 
Vol. 21, No. 12, 2010

Cornelius et al.

Sq

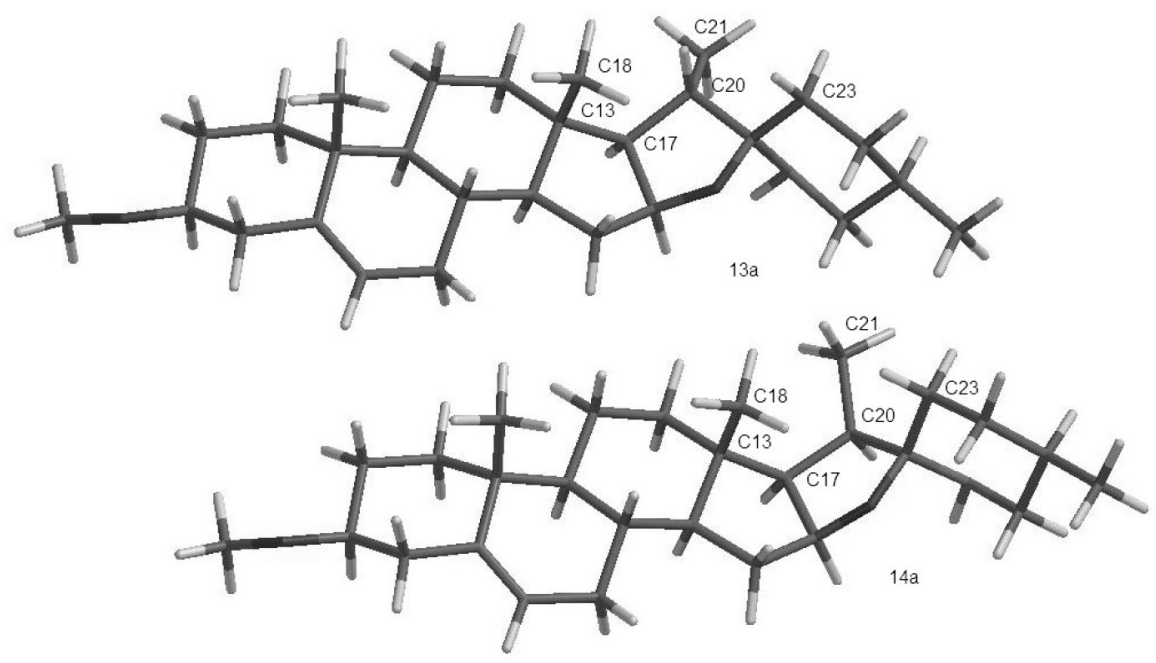

Figure S15. 3D representation of models 13a and 14a after optimization with the B3LYP/6-31G* DFT method. 